\title{
New Insight in The Molecular Mechanisms of Neurodegenerative Disease
}

\author{
Anna Meiliana ${ }^{1,2,}$, Nurrani Mustika Dewi ${ }^{1,2}$, Andi Wijaya ${ }^{1,2}$ \\ ${ }^{1}$ Postgraduate Program in Clinical Pharmacy, Padjadjaran University, Jl. Eijkman No.38, Bandung, Indonesia \\ ${ }^{2}$ Prodia Clinical Laboratory, Jl. Cisangkuy No.2, Bandung, Indonesia \\ *Corresponding author. E-mail: anna.meiliana@prodia.co.id
}

Received date: Jan 21, 2018; Revised date: Apr 24, 2018 ; Accepted date: Apr 26, 2018

\section{Abstract}

2 ACKGROUND: Redox and proteotoxic stress contributes to age-dependent accumulation of dysfunctional mitochondria and protein aggregates, and is associated with neurodegeneration. The free radical theory of aging inspired many studies using reactive species scavengers such as alpha-tocopherol, ascorbate and coenzyme-Q to suppress the initiation of oxidative stress. However, clinical trials have had limited success in the treatment of neurodegenerative diseases (NDDs).

CONTENT: The misfolding and aggregation of specific proteins is a seminal occurrence in a remarkable variety of NDDs. In Alzheimer's disease, the two principal aggregating proteins are $\beta$-amyloid $(A \beta)$ and tau. The abnormal assemblies formed by conformational variants of these proteins range in size from small oligomers to the characteristic lesions that are visible by optical microscopy, such as senile plaques and neurofibrillary tangles. Pathologic similarities with prion disease suggest that the formation and spread of these proteinaceous lesions might involve a common molecular mechanism, corruptive protein templating. The accumulation of redox modified proteins or organelles cannot be reversed by oxidant intercepting antioxidants and must then be removed by alternative mechanisms. Autophagy serves this essential function in removing damaged or dysfunctional proteins and organelles thus preserving neuronal function and survival.

SUMMARY: Senescent cells and their senescenceassociated secretory phenotypes (SASPs) may constitute a novel, understudied, and potentially important contributor to neuro-inflammation and subsequent neurodegeneration. Characterization of cellular senescence in the brain could uncover novel therapeutic targets for the prevention and treatment of chronic age-related NDDs.

KEYWORDS: brain, aging, neurodegeneration, DNA damage, senescence, neuro-inflammation, mitochondria, lysosome, proteostasis, prion, amyloidosis

Indones Biomed J. 2018; 10(1): 16-34

\section{Introduction}

Neurodegenerative disorders are becoming increasingly prevalent worldwide, and are a growing burden on the aging population.(1) According to a 2015 United Nations report on world population aging, the number of people aged 60 and older worldwide is projected to more than double in the next 35 years, reaching almost 2.1 billion people. $(2,3)$ Aging is a natural process characterized by a progressive functional decline of tissues, organs, and organ systems, which leads to an increased susceptibility to age-related diseases and, ultimately, to death. A persistently DNA damage response (DDR), known as "cellular senescence", is one of the main contributing factor to age-associated tissue dysfunction, reduced regenerative capacity, and agerelated diseases.(4-6).

Neurodegenerative diseases (NDDs) such as Alzheimer's disease (AD), Parkinson's disease (PD), amyotrophic lateral sclerosis (ALS), and frontotemporal lobar dementia are among the most pressing problems of developed societies with aging populations. Neurons 
carry out essential functions such as signal transmission and network integration in the central nervous system and are the main targets of NDD.(7) Neurodegeneration by definition disturbs the properties of the Central Nervous System (CNS) and therefore affects neuronal function, as well as the structure or survival of neurons.(7) The development of therapies aimed at mitigating or delaying age-related NDDs is a major priority for the biomedical community due to the enormous social, emotional and economic burden associated with them. The disappointing outcomes of dozens of phase III clinical trials of treatments for $\mathrm{AD}$ and $\mathrm{PD}$ indicate a need for fresh approaches to identify novel targets that drive processes that cause agerelated neuropathology.(8) Currently available treatments (social supports, mobility aides, and "Band-Aid" treatments for end-stage, downstream symptoms) are not directed at the root causes of age-related dysfunction. Treating chronic diseases one at a time does not suffice.(9)

Clearly, clinical practice would be transformed if mechanism-based treatments could be devised that break the link between fundamental aging processes and chronic diseases, making aging a modifiable risk factor. The recent awareness that age-related disorders can be driven by one or more basic aging processes has inspired efforts to identify these processes and develop strategies, preferably pharmacological in nature, to intervene.(10) Rapid advances in molecular genetics and neuroimaging will improve our understanding of the pathogenetic mechanism underlying the earliest stages of the detrimental processes increasing the vulnerability for neurodegeneration later in life.(11,12) Prevention of NDDs of the elderly might begin during the fetal and childhood life by providing the mothers and their children a healthy environment for the fetal and childhood development. This might also help to cope better with the life-long environmental influences and with genetic factors.

\section{Aging and NDD}

Population-based autopsy studies of the brains of aged people who had not been diagnosed with a neurological disease consistently report the presence of amyloid plaques, neurofibrillary tangles, Lewy bodies, inclusions of TAR DNA-binding protein 43 (TDP-43), synaptic dystrophy, the loss of neurons and the loss of brain volume in most of the brains.(12) These features vary greatly between individuals, with particular lesions dominating a particular brain or restricted to specific regions.(3)
The presence of age-related protein abnormalities and inclusion bodies in the aging brain points to defects in proteostasis, an idea that is supported by mounting evidence from experiments. According to one such hypothesis, in normal aging, macromolecules become oxidized and can no longer be degraded by lysosomes. This leads to the further production of lysosomal enzymes that are also unable to digest the cellular material. A well-known deposit that results from lysosomal inefficiency is lipofuscin, which is an accepted marker of aging for postmitotic cells.(13) Similarly, the increase in damaged proteins and dying cells that accompanies aging can overwhelm phagocytic processes and lead to an accumulation of material in lysosomes. Indeed, myelin debris have been demonstrated to accumulate in aging microglia, in which it forms insoluble, lipofuscin-like lysosomal inclusions.(14) With aging, and even more so with neurodegeneration, the brain shows increased levels of many lysosomal proteins and enzymes, and neurons and other cell types show abnormal endosomes, lysosomes and autophagosomes.(15-17)

The aggregation of misfolded proteins is a characteristic feature of aging as well as aging-related NDDs. $(18,19)$ The most common altered proteins observed in aging brains are hyperphosphorylated- $\tau(\operatorname{HP} \tau)$ and $\beta$-amyloid (A $\beta$ ) (i.e., hallmark lesions of $\mathrm{AD}$ ), $\alpha$-synuclein (SymbolS) (i.e., hallmark lesions of $\mathrm{PD} /$ dementia with Lewy bodies (DLB)), and transactive response TDP43 (i.e., hallmark lesions of frontotemporal lobar degeneration with TDP (FTLD-TDP), and amyotrophic lateral sclerosis (ALS)).(20-26) Each of these protein alterations seem to progress neuro-anatomically in an orderly manner from a presumed initiation/predilection site. When the most severe stages of the progression are reached, these altered proteins were considered to be causative of NDDs such as AD, PD, DLB, FTLD-TDP and ALS.(27-33)

Recently, a new entity, primary age-related tauopathy (PART), which describes neurologically unimpaired aged subjects with $\mathrm{HP} \tau$ pathology in the hippocampus, has been defined.(34) It has even been debated whether subjects with PART represent an early stage of AD or merely reflect a neurodegenerative process at an early stage.(35) Also, "acute or incidental" $\alpha \mathrm{S}$ pathology has been reported to be seen in $5 \%$ to $31 \%$ of the cognitively unimpaired aged subjects $(36,37)$, and $A \beta$ has been reported in the cortex of $39 \%$ to $82 \%$ of cognitively unimpaired aged subjects $(38,39)$. TDP43 pathology has been reported in $3 \%$ to $40 \%$ of cognitively unimpaired aged subjects. $(40,41)$ The later is frequently associated with hippocampal sclerosis. (42) Experimental evidence suggests a complex scenario, 
including mitochondrial dysfunction, compromised stress responses, synaptic rearrangements and altered protein expression, to cause age-related brain changes. neurodegenerations were traditionally defined as disorders with selective loss of neurons and distinct involvement of functional systems defining clinical presentation.

Classification of neurodegenerations is based on clinical presentation, anatomical regions and cell types affected, conformationally altered proteins involved in the pathogenetic process, and etiology if known, e.g., genetic aberrations. Currently, "the-winner-takes-it-all" approach supports classification of diseases according to the predominant protein that is deposited in the brain.(43) The basis of this classification is to evaluate where the deposits composed of particular proteins are found. Extracellular deposits comprise deposits with immunoreactivity for $\mathrm{A} \beta$ or prion protein $(\mathrm{PrP})$, while proteins that deposit intracellularly include $\tau, \alpha \mathrm{S}$, TDP-43, or so called FET proteins (FUS: fused in sarcoma, EWS: ewing sarcoma protein, TAF15: TATA-binding protein-associated factor 15). $(43,44)$ These proteins associate with sporadic and inherited forms, while there are further proteins, which are related to genetic diseases, like those linked to trinucleotide repeat disorders. These proteins deposit in various cell types (neuron, astro- and oligodendroglia). Indeed, some neurodegenerations show predominantly oligodendroglial protein deposits (like the $\alpha$-synucleinopathy multiple system atrophy, or tauopathies with globular glial inclusions) $(45,46)$, which raise the issue that non-neural cells are also important components of neurodegenerations pathology. Thus, evaluating proteins and pathways that are important in age-related neurodegeneration in the developing brain together with the characterization of mechanisms important during brain development with relevance to brain aging are of crucial importance.

Elucidation of complex pathogenetic routes characterizing the earliest stage of the detrimental processes that result in pathological aging represents an essential first step toward a therapeutic intervention which is able to reverse these pathological processes and prevent the onset of the disease.(11) Given that, NDDs in the elderly are common. Disease-free brains, especially in the oldestold, are rare. It is possible that normal brain aging forms a continuum with neurodegeneration and disease, and that stochastic factors, framed by a person's genetics and environment, determine the type of NDD that will dominate their brain eventually (Figure 1).

\section{DNA Damage and NDD}

Biological tissues require oxygen to meet their energetic demands. However, the consumption of oxygen also results in the generation of free radicals that may have damaging effects on cells. The brain is particularly vulnerable to the effects of reactive oxygen species (ROS) due to its high demand for oxygen, and its abundance of highly peroxidisable substrates. Oxidative stress is caused by an imbalance in the redox state of the cell, either by overproduction of ROS, or by dysfunction of the antioxidant systems.(47) ROS contribute to the development of neurodegeneration by modulating the function of biomolecules. ROS may target several different substrates in the cell, causing protein, DNA, RNA oxidation, or lipid peroxidation The oxidation products of

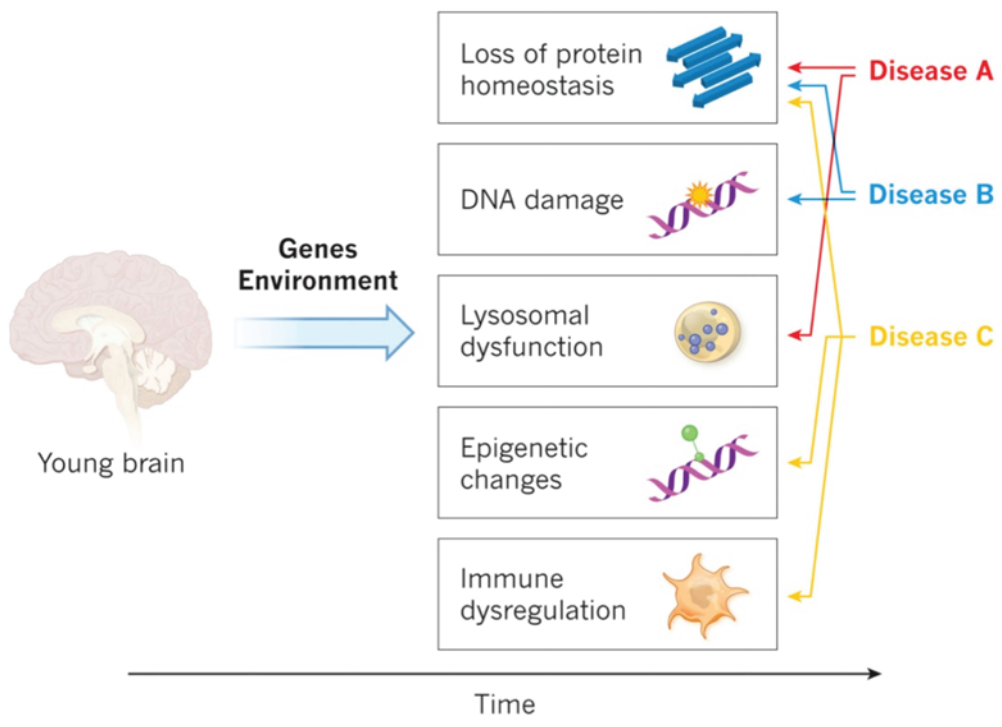

Figure 1. Cell-specific and pathway-specific acceleration of aging.(3) (Adapted with permission from Springer) 
polyunsaturated fatty acids, especially arachidonic acid and docosahexanoic acid which are abundant in brain, are malondialdehyde and 4-hydroxynonenal. ROS attacks protein, oxidizing both the backbone and the side chain, which in turn reacts with amino acid side chains to form carbonyl functions. ROS attacks nucleic acids in a number of ways, causing DNA-protein crosslinks, breaks in the strand, and modifies purine and pyridine bases resulting in DNA mutations.(47)

Damage to a cell's genomic DNA is particularly harmful because DNA is the blueprint for protein production and, unlike other molecules, it cannot simply be replaced by resynthesis. DNA damage induces mutations and chromosomal aberrations that can lead either to cellular dysfunction or to the formation of cancer, and encounters with certain DNA lesions can derail transcription and replication, and thereby trigger cell death, senescence, and aging (48). Accordingly, cells devote enormous resources for the purpose of genome maintenance and have evolved elaborate systems to repair damaged DNA.(49) The consequences of genomic instability manifest in at least three important ways with age (Figure 2). The first is an accumulation of unrepaired DNA damage, which can arise from a decrease in DNA repair activities with age. For instance, a decline in the efficiency of base excision repair (BER) and non-homologous end joining (NHEJ) due to a reduction in the activity of DNA glycosylases and DNA- dependent protein kinase (DNA-PK), respectively, has been reported in the literature. An age-dependent attenuation in DNA repair capacity has also been reported in the rodent and human brain.

Another way in which DNA damage participates in aging is through the erroneous repair of DNA lesions that results in mutations.(50) In contrast to unrepaired lesions, which are reversible, mutations are irreversible and can therefore be highly problematic. In addition to direct alterations to the composition and structure of DNA, the formation of DNA damage also elicits substantial changes to chromatin organization.

Thus, DNA damage could progressively alter chromatin conformation, and thereby, gene expression patterns, with age. In fact, a number of studies have reported age-associated changes in the epigenome (50-52), although precisely what fraction of these changes is a result of DNA damage remains unclear. In addition to normal aging, defective DNA repair has also been linked with ageassociated neurodegenerative disorders such as AD, PD and ALS. For instance, elevated levels of DNA strand breaks, a reduction in the levels of double strand break (DSB) repair proteins such as DNA-PKcs and MRE11-RAD50-NBS1 (MRN) complex proteins, and decreased BER activity have been described in $\mathrm{AD}$ patients compared to age-matched controls (53-56). Similarly, elevated levels of oxidative lesions and single strand breaks (SSBs) have been reported

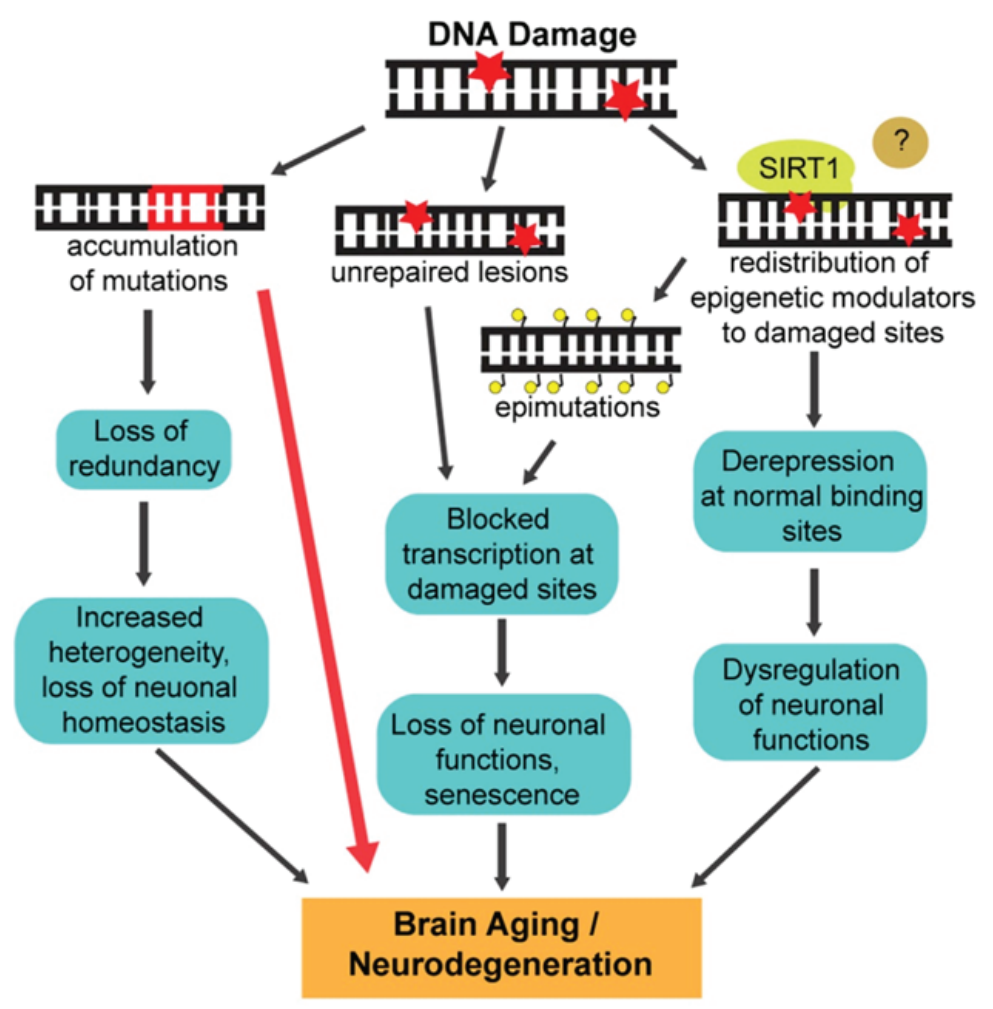

Figure 2. The Consequences of DNA Damage in Aging and Neurodegeneration.(49) (Adapted with permission from Cell Press). 
in the neurons of ALS patients and damage to mitochondrial DNA has been documented in PD.(57-59) While these studies certainly raise the possibility that defects in the DDR underlie brain aging and the development of age-related neurodegenerative disorders,

It is becoming increasingly clear that the DNA damage response is important during both neural development and in the mature nervous system. Mutations in core DNA repair factors are either incompatible with life, or, even when tolerated, manifest in severe neurodevelopmental disorders. On the other hand, determining the specific contribution of DNA damage to brain aging and neurodegeneration remains a complex problem. The vulnerability of postmitotic neurons to certain types of DNA damage (such as oxidative lesions or certain DNA strand break lesions) coupled with a gradual decline in the activities of corresponding repair mechanisms could lead to their accumulation with age and contribute to brain aging and neurodegeneration.(49) Identification of a previously uncharacterized genetic disease highlights DNA repair as a shared mechanism in neurodegenerative disorders, and suggests potential therapeutic approaches to tackling them. An error in error-correcting might also happens (Figure 3).(1) DNA-repair enzymes also modify the age of onset of

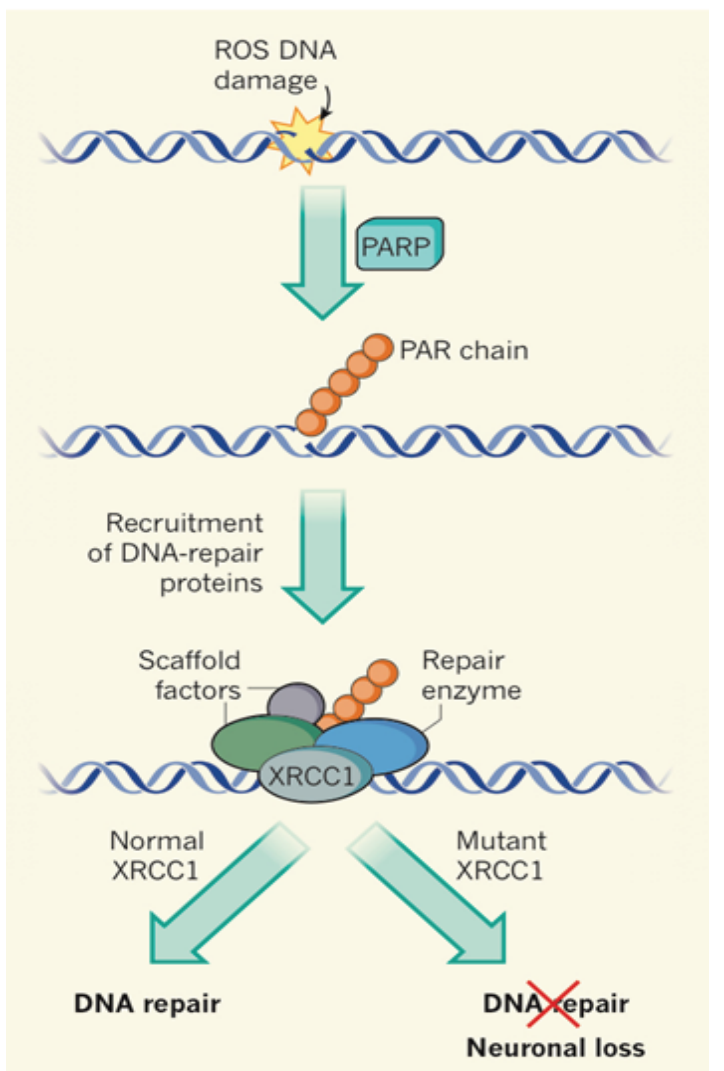

Figure 3. Errors in an error-correcting mechanism.(1) (Adapted with permission from Springer). several other NDDs caused by polyglutamine expansion. In addition, DNA-repair mechanisms have been implicated in the pathogenesis of such polyglutamine diseases. Perhaps clustering of mutant polyglutamine-expanded proteins near DNA inhibits the recruitment and release of repair enzymes, interfering with cellular DNA repair. Relationships between the pathways involved in DNA repair and in polyglutamineexpansion diseases are becoming apparent. $(1,60)$

How do DNA-repair defects bring about neurodegeneration? One possibility is that, over time, aberrant DNA repair results in a progressive accumulation of oxidative damage to DNA. This damage causes broad changes, both in DNA sequence and in epigenetic modifications, which alter gene expression without changing the underlying DNA. Over time, these changes could cause a loss of normal neuronal functi and DNA-damage levels would cross a threshold, leading factors involved in maintaining genomic integrity, such as the protein $\mathrm{p} 53$, to trigger programmed cell death and neuronal loss.

In the future, poly ADP ribose polymerase (PARP), ataxia-telangiectasia mutated (ATM), p53 and other repairrelated proteins could prove to be therapeutic targets for NDD. Hopes for treating these diseases 25 years ago focused on DNA and genetic studies.w We may now have come full circle, back to DNA. Time, and further studies, will be needed to elucidate these mechanisms in more detail, and to determine whether such treatments could be useful in NDDs.(1)

\section{Cellular Senescence and The SASP in NDD}

The cell cycle consists of elaborate feedback mechanisms and regulatory checkpoints that are typically divided into four phases: S-phase, during which DNA replication occurs, M-phase, where cell division, or mitosis, takes place, and the gap phases that separate the two; G1 and G2, respectively. Additionally, quiescent cells, such as many of the neurones in the adult hippocampus, exist in a non-dividing, silent phase known as G0. Once in this phase, cells are deemed terminally differentiated, meaning they are not capable of re-entering the cell cycle. $(61,62)$ It is in this capacity that vulnerable neurones are affected. As increasing evidence indicates, cells that exist in G0, and thus are no longer mitotically active, become wrongly reactivated in $\mathrm{AD}$ and other NDDs, and are forced through a cell cycle that they are no longer capable of completing.(63-66) 
Senescence is a process of mitotic arrest of the cell cycle, which is started in the G1/S check-point.(67) During this state the cell experiences several modifications, such as changes in morphology, metabolism and expression of cytokines and growing factors. These changes result in what is known as the SASP.(68) It has been considered that senescence might be caused by a series of biological processes, including telomere shortening, oxidative stress, DNA damage, calcium dysregulation, misfolded proteins and oncogene expression.(69) Senescence is divided into replicative senescence, stress-induced premature senescence (SIPS) and oncogene-induced senescence, being SIPS the most important for the CNS.(70) Premature senescence caused by stress can involve telomere-dependent or telomere-independent mechanisms.(67) Mitochondria play an important role in senescence, as they are among the organelles that produce more oxidative stress and their dysfunction has been associated with high levels of ROS in senescent cells (71) and during aging (72).

Cellular senescence has been described more than 50 years ago as a process that limits the growth of normal human cells in culture. Cellular senescence is closely interconnected with aging, longevity, and age related diseases by sharing common genes, regulators, and multiple signaling pathways.(73) Senescence is associated with cellular mechanisms that trigger NDDs and other aging-associated process. It has been shown that senescence involves mitochondrial dysfunction, morphological changes, activation of p38 mitogen-activated protein kinases (p38MAPK) and increased secretion of proteins and factors, such as $\alpha$-galactosidase and interleukin (IL)-6, by astrocytes and neurons $(74,75)$, in both normal aging and neurodegenerative conditions, such as AD and PD. Another important factor for senescence is telomere length, although its role in neurological diseases is still controversial. Several studies have found that telomere loss is associated with diseases such as schizophrenia (76), depression (77) and AD (78). A recent meta-analysis of 13 primary studies (including $860 \mathrm{AD}$ patients and 2022 controls) found shorter telomeres in $\mathrm{AD}$ patients.(79)

In addition to arresting growth, senescent cells express a SASP, the robust secretion of many inflammatory cytokines, growth factors and proteases. $(80,81)$ SASP factors include several ILs, monocyte chemotactic proteins (MCPs), growth-related oncogenes (GROs), and inflammatory cytokines as granulocyte-macrophage colony stimulating factor (GM-CSF) and macrophage inflammatory proteins (MIPs), among others. $(80,82,83)$ SASP factors can have potent effects on neighboring cells and thus can alter local and systemic tissue milieus. In the brain, it seems that the increase in $\mathrm{p} 16^{\mathrm{INK} 4 \mathrm{a}}$ expression is linked to the decline in the number of progenitor cells and consequently to reduced neurogenesis.(84) Moreover, studies on animal models of accelerated aging have indicated that the premature aging is associated with an increased level of senescence markers in their tissues.(85) The aging brain displays several typical stress response indicators: (i) increased oxidative stress with damage in nuclear DNA (86) and in cellular proteins (87), (ii) protein misfolding and aggregation (88), (iii) disturbances in calcium homeostasis (89), (iv) mitochondrial dysfunction and energy deficiency (90) and (v) accumulation of pigmented autophagic vacuoles containing lipofuscin, neuromelanin and ceroid (91). Many of these changes are typical changes associated with cellular senescence and the SASP. Several gene expression profiling studies in brain have revealed that aging is linked to the increase in the expression of stress response and inflammatory genes and a decrease in gene expression associated with synaptic transmission, calcium homeostasis and mitochondrial function (92-94).

The brain is basically composed of two different kinds of cells: glial cells (astrocytes and microglia) and neurons. Astrocytes are involved in the modulation of synaptic neuronal function and plasticity (95), while microglia work as resident macrophages $(96,97)$, providing immune surveillance and mediating innate immune responses to pathogens or injuries. Neurons are terminally-differentiated post-mitotic cells while glia, particularly microglia, are the only adult cell type in the CNS that exhibit a significant mitotic potential, and are susceptible to telomere shortening. Increasing evidences are showing that senescent cells are detectable in mammalian brains along with the aging process, and may also be implicated in NDDs. $(8,98,99)$ As an indicator of cellular senescence telomere length has been proposed as a biomarker of human aging.(100) In general, telomere length reflects the balance between additions and losses of TTAGGG repeats (101) and it can be accelerated by many factors, such as oxidative stress, replication stress, and inflammation (102). Epidemiologists have measured telomere length in cohort studies and suggested that measurement of telomere length in white blood cells can be used as a surrogate marker of telomere length in other tissues/organs (103). Overall these observations suggest that telomere stability and maintenance are required for brain functions. Advanced age and presence of intra-cerebral A deposit are known to contribute to the development of neurodegenerative alterations in AD. Microglial cells exhibit significant telomere shortening and reduction in telomerase 
activity in normally aging rats as well as a faster telomere shortening rate in human microglia along with dementia progression.(104) The authors suggested that telomere shortening contributes to degeneration of microglia as a contributing factor in the pathogenesis of AD.(6)

Strategies directed to counteract the molecular changes in senescent cells have been explored. Several studies have found that telomerase has neuroprotective effects in the brain and it has been shown that its expression and activity are increased after injury. Telomerase is a ribonucleoprotein responsible for telomere length maintenance, and it has been demonstrated that its protein component (telomerase reverse transcriptase (TERT)) has extra-telomeric functions, which are important for post-mitotic cells such as neurons. (105) TERT overexpression is associated with decreased ROS levels (105) and with the reduction of excitotoxicity induced by N-methyl-D-aspartate (NMDA) in neurons (106). TERT has effects on neuronal survival because it regulates Bcl2/Bax expression.(107) Therefore, TERT could be considered as a key protective protein since it may decrease some secretory phenotypes of senescence in the brain, which have been associated with the onset of NDDs (Figure 4).(79,108)

Upon stress signaling events, such as those triggered by the exposition to a high dose of exogenous $\mathrm{H}_{2} \mathrm{O}_{2}$, TERT is translocated from the nucleus to the cytoplasm and this process is regulated by Src kinase family inhibitor protein phosphatase 1 (PP1), since TERT is phosphorylated in a tyrosine at position 707.(109) In the nucleus, TERT is regulated by protein tyrosine phosphatase 2 (Shp-2). (110) TERT is imported from the cytoplasm to the nucleus through Akt-mediated phosphorylation at serine 227 and its interaction with heath shock protein 90 (Hsp90). TERT localization is also regulated by interaction with other proteins such as nuclear factor kappa $\mathrm{B}(\mathrm{NF}-\kappa \mathrm{B})$ and tumor necrosis factor $\alpha$ (TNF- $\alpha$ ) (111). TERT has a mitochondrial targeting signal and, therefore, TERT can enter the mitochondrial matrix where it interacts with mitochondrial DNA and mitochondrial tRNA (112). Several studies have evidenced that TERT is translocated from the nucleus to the

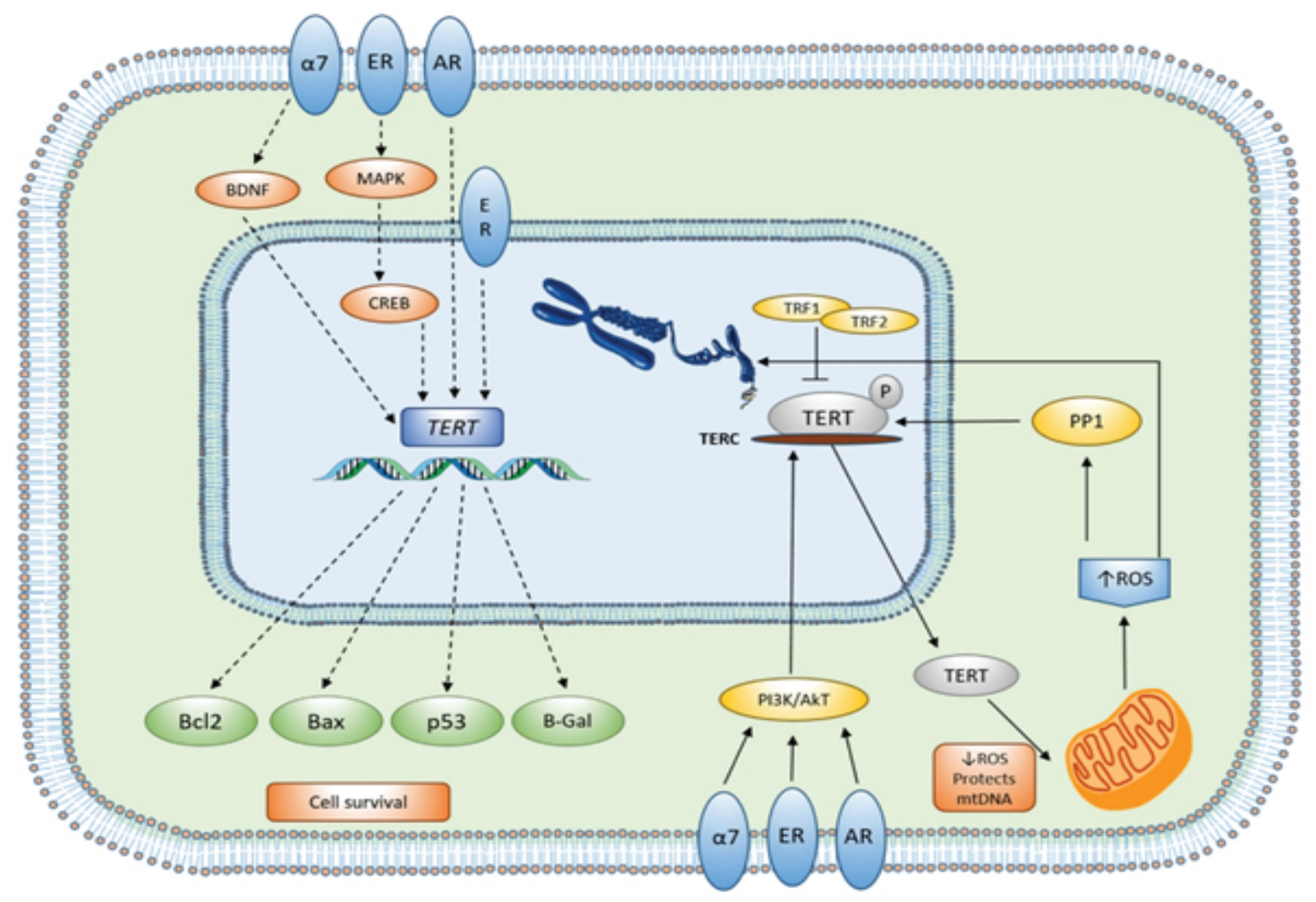

Figure 4. Overview of possible neuroprotective mechanisms of TERT in cells from the CNS and possible strategies to increase TERT expression and telomerase activity.(108) (Adapted with permission from Esevier B.V). BDNF: brain-derived neurotrophic factor; MAPK: mitogen-activated protein kinases; CREB: cAMP responsive element binding; TRF: telomeric repeat factor; Bcl2: B-cell lymphoma 2; Bax: Bcl-2-associated X; PI3K: phosphoinositide 3-kinase. 
mitochondria in response to oxidative stress. $(109,113,114)$ Recently, TERT has been postulated as a therapeutic target for NDDs due to its protective role in oxidative stress and DNA damage after injury, especially in injured spinal cord (115), neonatal hypoxic-ischemic brain injury (116) and in an amyotrophic lateral sclerosis animal model (117). However, few studies have analyzed TERT expression and telomerase activity in the human CNS.(108)

\section{Neuro-inflammation in NDD}

Aging is a ubiquitous complex phenomenon that results from environmental, stochastic, genetic, and epigenetic events in different cell types and tissues and their interactions throughout life. A pervasive feature of aging tissues and most if not all age-related diseases is chronic inflammation. "Inflammaging" describes the low-grade, chronic, systemic inflammation in aging, in the absence of overt infection ("sterile" inflammation), and is a highly significant risk factor for both morbidity and mortality in the elderly people.(118) Inflammaging most likely derives from, but is not limited to, the sources described here. These sources are not mutually exclusive, and their relative contributions require further studies. One source of inflammaging could be the damaged macromolecules and cells (self-debris) that accumulate with age due to increased production and/or inadequate elimination. Self-debris released as a consequence of cell/ organelle injury can mimic bacterial products and function as endogenous "damage"-associated molecular patterns that activate innate immunity.(119)

A second source of inflammaging might be represented by harmful products produced by the microbial constituents of the human body, such as oral or gut microbiota, which can leak into surrounding tissues and the circulation.(120) Presumably, the ability of the gut to sequester these microbes and/or their products declines with age, leading to chronic low-grade inflammation. Alternatively, the gut microbiota itself might change with age so that the microbes present in the aged, but not young, gut elicit an inflammatory response. (119)

Mitochondria play a major role in inflammaging and in the activation of NLR family pyrin domain containing 3 (Nlrp3) inflammasome. The Nlrp3 inflammasome is a multiprotein complex that can activate pro-caspase- 1 in response to cellular danger resulting in the processing and secretion of the proinflammatory cytokines IL-1 $\beta$ and IL18. Most activators of the Nlrp3 inflammasome induce the generation of mitochondrial ROS. Third, inflammaging might be due to cellular senescence. Senescence is a cellular response to damage and stress. Mechanistically, senescent cells likely fuel age-related disease because they secrete numerous proinflammatory cytokines that modify the tissue microenvironment and alter the function of nearby normal or transformed cells. $(121,122)$ Senescent cells accumulate with age in many tissues and are prominent at sites of many age-related pathologies.

Emerging evidence suggests that inflammation has a causal role in disease pathogenesis, and understanding and control of interactions between the immune system and the nervous system might be key to the prevention or delay of most late-onset $\mathrm{CNS}$ diseases. In $\mathrm{AD}$, neuro-inflammation is not a passive system activated by emerging senile plaques and neurofibrillar tangles, but instead contributes as much (or more) to pathogenesis as do plaques and tangles themselves.(123) The important role of neuro-inflammation is supported by findings that genes for immune receptors, including triggering receptor expressed on myeloid cells 2 (TREM2) (124) and cluster of differentiation (CD)33 $(125,126)$, are associated with $\mathrm{AD}(127)$.

Detection of pathological triggers is mediated by receptors that recognize danger-associated molecular patterns (DAMPs) or pathogen-associated molecular patterns (PAMPs). In $\mathrm{AD}$, microglia are able to bind to soluble $\mathrm{A} \beta$ oligomers and $A \beta$ fibrils via cell-surface receptors, including SCARA1, CD36, CD14, $\alpha 6 \beta 1$ integrin, CD47, and toll-like receptors (TLRs) such as TLR2, TLR4, TLR6, and TLR9 (128-131), and this process is thought to be part of the inflammatory reaction in $\mathrm{AD}$. Binding of $\mathrm{A} \beta$ with $\mathrm{CD} 36$, TLR4, and TLR6 results in activation of microglia, which start to produce proinflammatory cytokines and chemokines. In turn, genetic deletion of CD36, TLR4, or TLR6 in vitro reduces $A \beta$ - induced cytokine production $(130,132,133)$ and prevents intracellular amyloid accumulation and activation of multiprotein complexes known as inflammasomes (133).

Neuroinflammation has been famously difficult to define in relation to NDD. In contrast, neuroinflammation in multiple sclerosis (MS) is unambiguous, comprising often florid infiltration of the CNS parenchyma by bloodderived lymphocytes and monocyte-derived macrophages, accompanied by frank impairment of blood-brain barrier (BBB) function and intense glial reaction. Neuroinflammation in diseases such as $\mathrm{AD}, \mathrm{PD}$, and ALS is typified instead by a reactive morphology of glial cells, including both astrocytes and microglia, accompanied by low to moderate levels of inflammatory mediators in the parenchyma. This reaction, both cellular and molecular, is not distinguishable between one disease and another or from 
other conditions such as stroke or traumatic injury. Given this lack of specificity, it is easy to conclude that the glial reaction is secondary to neuronal death or dysfunction and is accordingly unlikely to provide useful targets for therapeutic intervention or topics for intensive investigation.(7)

Given this difficulty of using reductionist experimental approaches to evaluate glial neuroinflammatory properties, and in view of the nonspecific nature of cardinal inflammatory changes in glia during NDD, it seems reasonable to propose an all-purpose definition of neuroinflammation in neurodegeneration: contributions by glial cells, elements of the $\mathrm{BBB}$, or systemic inflammatory processes that are harmful or beneficial to the severity of NDD. This broad definition acknowledges the primacy of neurons in brain function and disease and further recognizes that the glial reaction to neuronal injury, dysfunction, or death may be helpful or harmful (or neutral).(7) In addition, as inflammation in $\mathrm{AD}$ primarily concerns the innate immune system, unlike in 'typical' neuroinflammatory diseases such as multiple sclerosis and encephalitides, the concept of neuro-inflammation in AD may need refinement.(134)

\section{Mitochondrial - Lysosomal Dysfunction in NDD}

Neurons have an exceptionally high demand for ATP, which is needed for axonal transport, maintenance of ion gradients and membrane potential, and generation of synaptic vesicles. ATP production in neurons relies predominately on oxidative phosphorylation. Therefore, mitochondrial health is essential for neuronal function.(135) Given these unique features of neurons, the nervous system may be especially sensitive to mitochondrial damage. Dysfunctional mitophagy is closely linked to PD, a neurodegenerative disorder characterized by a loss of dopaminergic neurons in the substantia nigra as well as the accumulation of Lewy bodies, a form of protein aggregates.(136)

Aging is associated with a loss of physiological integrity, including an imbalance in proteostasis and an increase in mitochondrial dysfunction, which can be caused by compromised autophagy and its subtype mitochondrial autophagy, termed mitophagy. Autophagy is the process by which cellular components are degraded and recycled within the cell. Autophagy can refer to the nonspecific, cell-wide degradation of organelles or misfolded proteins in nutrient-starved conditions, as well as the removal of specific damaged or superfluous organelles. Aging and age-related pathologies are associated with reductions in autophagy (137), and emerging evidence suggests that the upregulation of autophagy may delay the onset and ameliorate the symptoms of age-related phenotypes (138). A reduction in autophagy leads to neurodegeneration in mice (139-141) and is thought to contribute to several NDDs in humans (17). Mitochondria, classically referred to as the "powerhouse" of the cell, produce cellular energy in the form of ATP. However, a large body of work has established additional and synergistic roles of the mitochondria in the regulation of cellular homeostasis.(142) Mitochondrial dysfunction is considered a hallmark of aging (143), and is implicated in apoptosis, senescence, genome instability, inflammation, and metabolic disorders $(142,144)$. The term "mitophagy" was first coined by Dr. Lemasters in 2005. (145) Since then, mitophagy has been linked to various diseases, including neurodegenerative disorders (146) such as PD (147), Huntington's (148), and AD (149), as well as normal physiological aging (150).

Determining what controls mitochondrial fitness is important for a better understanding of neurodegeneration and arming us with the knowledge that may help design better therapeutic strategies. How cellular bioenergetics, oxidative stress and autophagic-lysosomal activities are cross regulated is also important. It is clear that mitochondrial activity and oxidative stress are intertwined as mitochondria are sensitive to ROS damage while simultaneously generating ROS for cell signaling. Indeed, inhibiting the mitochondria's antioxidant defense mechanisms is deleterious to not only the mitochondria, but the cell as a whole, as best evidenced by superoxide dismutase 2 (SOD2) deletions or mutations.(151) Furthermore, inhibition of the mitochondrial glutathione transporter increases neuron sensitivity to oxidative and nitrosative stress.(152) The same degree of oxidative stress may then induce variable effects on bioenergetic programs depending on the maintenance of mitochondrial quality and coordination between biogenesis and mitophagy.(153) The importance of autophagy in aging is supported by observations that yeast, C.elegans and flies with impaired autophagy have decreased lifespan. This contributes to the notion that that autophagy plays an important role in the aging.(154-156)

Furthermore, pharmacologic or genetic manipulations that increase life span in model organisms often stimulate autophagy $(138,157-163)$. For example, inhibition of mammalian target of rapamycin (mTOR) by rapamycin, which enhances autophagy, extends health span and lifespan in model organisms.(164) The mechanisms of the effect of rapamycin are pleiotropic, including inhibition of protein synthesis, alteration of transcriptomes, modulation of 
inflammation, and improvement of cerebral blood flow, in addition to regulation of autophagy, mitophagy and thereby mitochondrial function.(157,161,165-177) Taken together, these examples provide strong support for the concept that autophagy plays a critical role in maintaining a normal lifespan and healthy neuronal aging, and that its decline is inexorably tied to age related pathologies (Figure 5).(178)

Degradation of dysfunctional mitochondria is carried out by the autophagy-lysosomal pathway. Many lysosomal diseases result in deficient autophagic degradation of cellular materials. The alteration of mitochondrial morphology and decreased respiratory chain activity varies in both extent and characteristics in tissues and isolated mitochondria among these diseases.(179) The lysosomotropic agent chloroquine or the lysosomal protease cathepsin D inhibitor pepstatin A have both been shown to increase the formation of reactive species.(180-184) Improving lysosomal biogenesis, increasing specific hydrolases, or decreasing lysosomal protease inhibitors have all been explored as neuroprotective strategies.(185-187) Here we highlight some of the evidence that autophagy may serve as an antioxidant and anti-proteotoxicity pathway and provide a beneficial impact on neuronal bioenergetic health and survival.(178)

Autophagy is important for redox homeostasis, mitochondrial quality control, cell proliferation and survival.(153,188,189) Furthermore, studies have found that autophagy and lysosomal gene expression may be coordinately regulated at transcriptional and post-transcriptional levels, and that genetic mutations of autophagy genes lead to abnormal cell and tissue homeostasis.(190-193) It is well recognized that mitochondrial dysfunction and increased oxidative stress play important roles in brain aging and the development of NDDs. Our recent findings that decreased mTOR signaling and dietary restriction are novel stimuli for mitochondrial localization of TERT protein, and the role of the telomerase protein TERT in brain on lowering mitochondrial ROS in an mTOR signaling dependent manner, therefore identify new players and connections in an ever bigger network of signaling events in the brain. Consequently, mTOR signalling and TERT protein could be potential therapeutic targets for neuropathological conditions via improvement of mitochondrial quality and decreased oxidative stress. $(194,195)$

\section{Proteostasis and Protein Seeding Defects in NDD}

Atypical mammalian cell contains more than 10,000 different proteins that are involved in virtually all its biological processes. Following their synthesis on ribosomes as linear chains of amino acids, proteins generally must fold to unique three-dimensional structures to become functionally active.(196) Proteins are essential to cellular metabolism and communication, and they form the framework on which cells and tissues are built. To undertake these roles, most

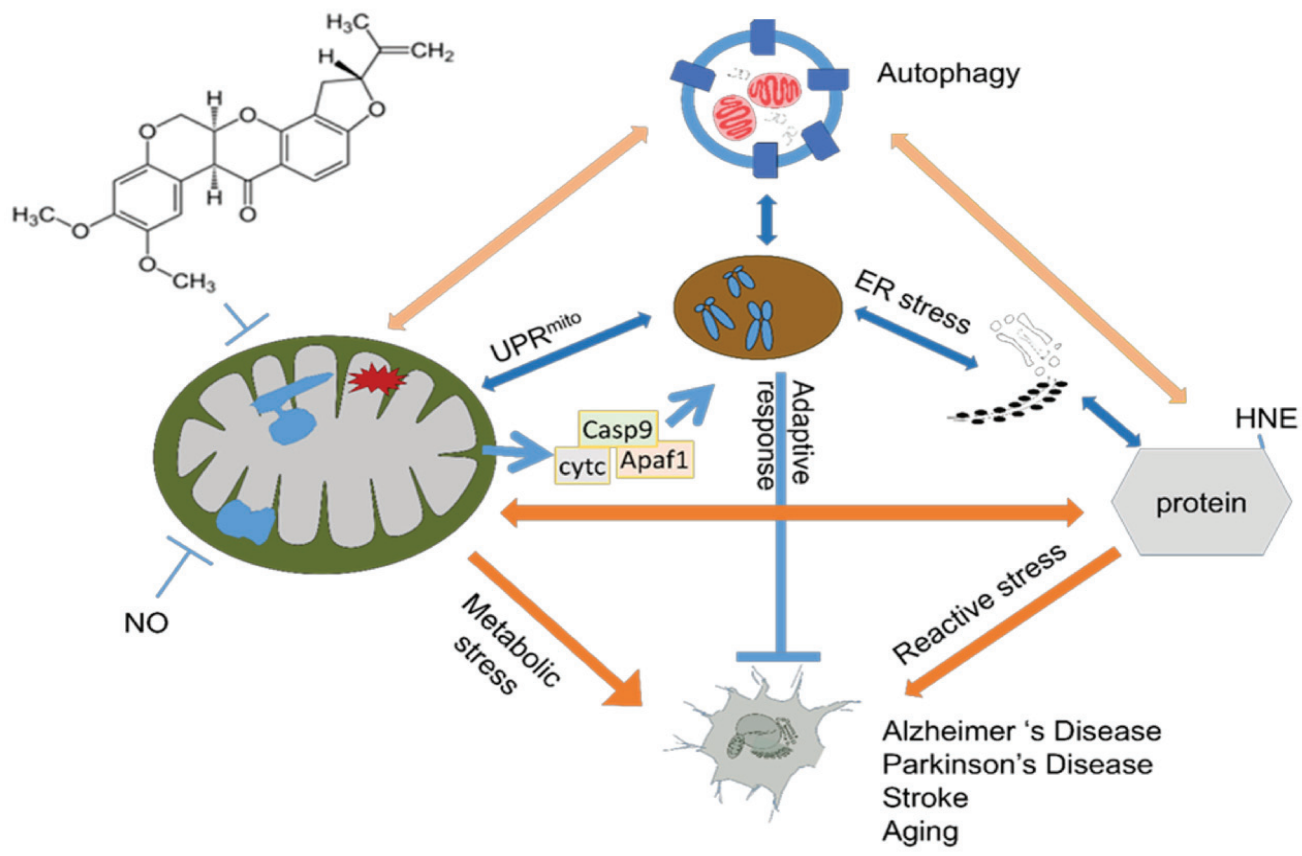

Figure 5. Autophagy serves as an essential neuroprotective pathway in response to mitochondrial dysfunction and oxidative stress. (178) (Adapted with permission from Redmann M). 
proteins fold into a specific, three-dimensional architecture that is largely determined by their distinctive sequences of amino acids. Others have a degree of structural flexibility that enables them to tailor their shape to the task at hand. $(197,198)$ Hence, it is critical for cells to maintain an efficient quality-control system that ensures the proper production, folding and elimination of proteins.(199,200) When a protein misfolds and evades normal clearance pathways, a pathogenic process can ensue in which the protein aggregates progressively into intracellular and/ or extracellular deposits. The consequence is a diverse group of disorders, each of which entails the aggregation of particular proteins in characteristic patterns and locations. $(20,21,33,201)$ New insights into the ontogeny of these proteopathies are beginning to emerge from the unusual properties of the prion, arguably one of the most provocative molecules in the annals of medicine.(202)

Because the ability to form cytotoxic aggregates is a widespread feature amongst proteins, cells contain an extensive network of factors to safeguard the integrity of the proteome, collectively referred to as the protein homoeostasis proteostasis network (PN). Molecular chaperones of various classes have a central role within the PN by mediating the folding of newly synthesized proteins, the refolding of stress-denatured proteins and the transfer of irreversibly misfolded proteins to the protein degradation machineries. Chaperones perform these functions primarily by preventing the aggregation of misfolded and incompletely folded protein molecules in the densely crowded cellular milieu, and therefore provide protection against cytotoxic protein species. The capacity of the chaperone system to

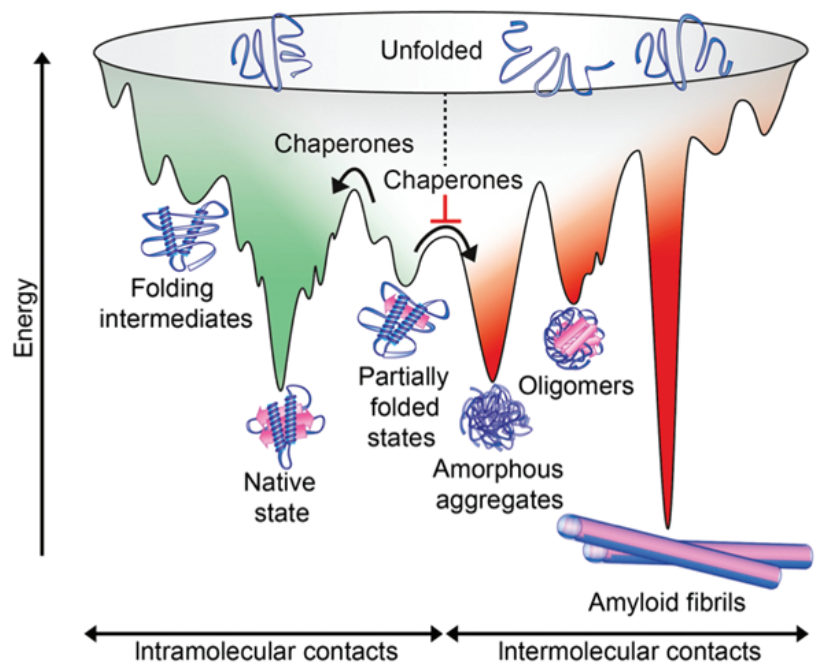

Figure 6. Off-pathway reactions of protein folding leading to aggregation.(196) (Adapted with permission from The Association for the Publication of the Journal of Internal Medicine). prevent or reverse toxic aggregates declines during aging, facilitating the manifestation of a range of NDDs and other pathologies (Figures 6).(196)

Amyloid diseases, or the amyloidoses, are characterized by the deposition of cross- $\beta$-sheet amyloid fibrils consisting of misfolded and/or misassembled proteins.(203-205) The amyloid fibrils that are the pathological hallmark of these disorders can be either deposited systemically or localized to specific organs. The development of amyloidosis is often linked to aging and is associated with a decreased quality of life and substantial suffering for both patients and their families. AD is an example of a localized cerebral amyloidosis and type 2 diabetes mellitus is an example of localized extracerebral amyloidosis; both diseases are associated with aging.(206)

Transthyretin (TTR) (207), immunoglobulin light chain (LC) (208), serum amyloid A (SAA) (209), and $A \beta$ (210) are examples of more than thirty human proteins whose misfolding and/or misassembly into a variety of aggregate structures appear to cause a spectrum of degenerative disorders (211). These so-called amyloid diseases are named after the cross- $\beta$-sheet aggregates, or amyloid fibrils, that are the pathological hallmarks of these maladies. $(212,213)$ Amyloid fibrils in a specific disease are generally composed predominantly of one protein5. Amyloid fibrils from different diseases and composed of different proteins exhibit similar structural features.(212)

The origin of amyloidosis is either sporadic, i.e., from the normal protein sequence, or hereditary (familial), i.e., from a protein harbouring one or more point mutations. (214) In addition, there re infectious forms of amyloidosis, such as the transmissible spongiform encephalopathies caused by the aggregation of prion protein. $(214,216)$ The aggregation of specific proteins is hypothesized to underlie several degenerative diseases, collectively called amyloid disorders.(217) Progressive accumulation of aggregates of specific proteins in the brain is a defining feature of many common NDDs, including AD, PD and frontotemporal dementia (FTD).(204,218) Certain rare infectious neurological diseases known as transmissible spongiform encephalopathies (TSEs) are associated with abnormal folding and aggregation of $\operatorname{PrP}$ (219), and the steady accumulation of PrP aggregates is a necessary prequel to neurodegeneration in most TSEs. It has been speculated that the protein deposits present in other NDDs may form and spread from region to region in a manner analogous to that of misfolded PrP in TSEs.(220,221) A recent comprehensive review from scientist who support this hypothesis concluded 
that "the paradigm of pathological protein propagation in NDD is now firmly established".(222)

Prions ('proteinaceous infectious particles') are unconventional infectious agents consisting of misfolded PrP molecules. In their misshapen state, the molecules aggregate with one another and impose their anomalous structure on benign PrP molecules.(223-226) Prions thus act as corruptive templates that incite a chain-reaction of PrP misfolding and aggregation. As prions grow, fragment and spread, they perturb the function of the nervous system and ultimately cause the death of the affected individual. The essence of prion disease is a crystallization-like chain reaction by which malformed $\operatorname{PrP}$ seeds force naive $\operatorname{PrP}$ molecules into a similar pathogenic architecture. Recent findings now suggest that this 'prion paradigm' also underlies the ontogeny of a widening spectrum of maladies, including common age-related NDDs such as AD and PD. In many of these disorders, as in prion disease, the aggregating proteins form characteristic lesions generically known as amyloid. $(202,227)$

The pathogenic spread hypothesis suggests that the progressive accumulation of protein aggregates across neuronal populations and brain regions that is observed in common NDDs $(21,23,232)$ is analogous to the accumulation of PrP3 within the brain in TSEs, in terms of both its mechanisms and its contribution to symptom progression (Figure 7). Proponents of this hypothesis therefore characterize the spreading mechanism in diseases such as AD, PD or FTD as 'prion disease' (220), prion-like $(221,228,229)$ or 'prionoid' $(230,231)$.

Principal alternative hypothesis for the progressive involvement of regional populations of neurons in protein misfolding diseases is the concept of selective neuronal vulnerability. According to this older concept, certain neurons are intrinsically more vulnerable to the underlying pathogenic processes of a disease (such as those that cause the misfolding and aggregation of a certain protein) than others $(233,234)$, perhaps because of their gene expression profiles, and that these vulnerable neurons thus become dysfunctional and structurally abnormal earlier than the others. The pathogenic spread hypothesis tends to emphasize a non-cell-autonomous mechanism of disease, whereas the selective neuronal vulnerability hypothesis tends to emphasize a more cell-autonomous mechanism.(232)

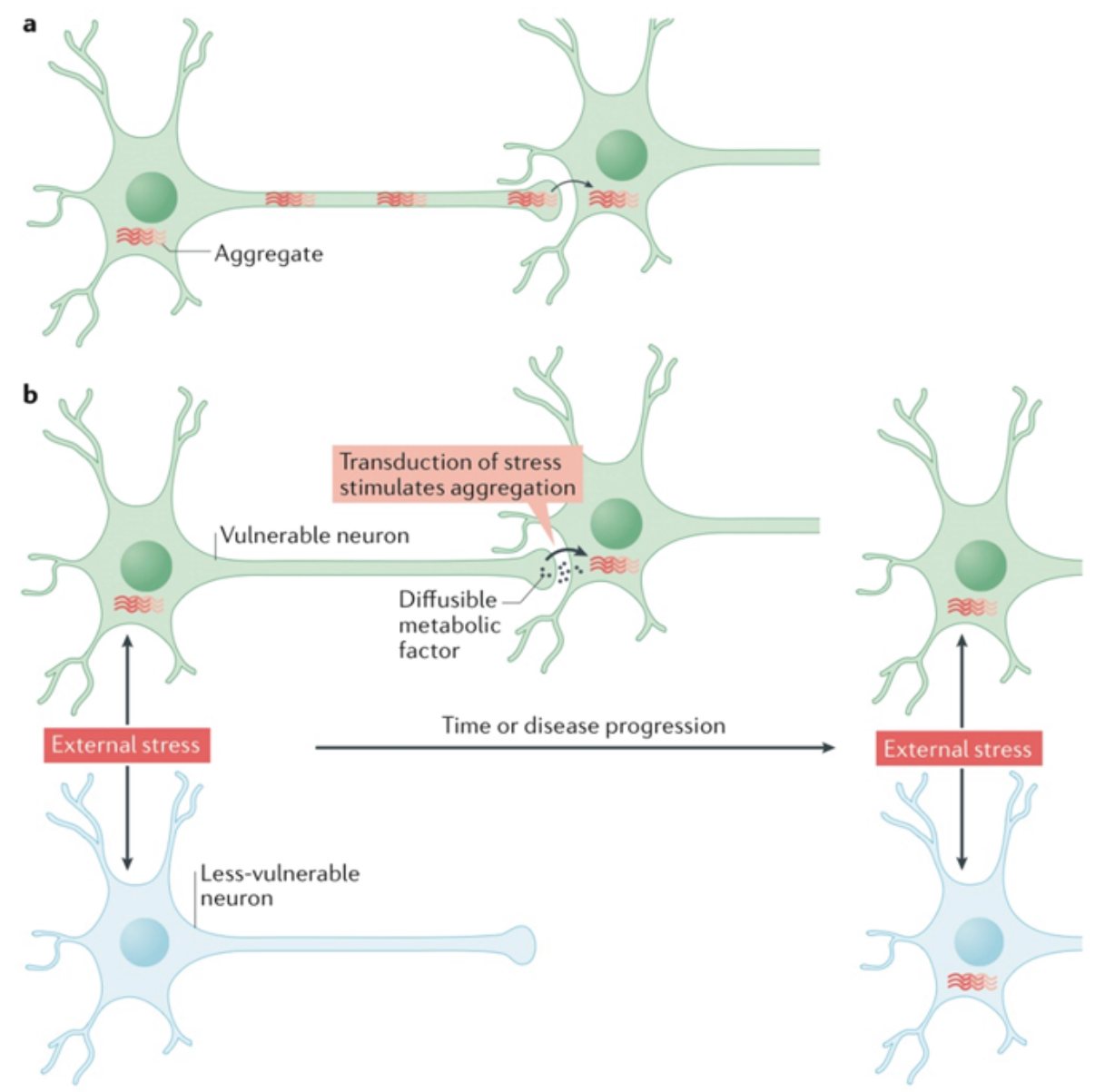

Figure 7. The pathogenic spread and selective vulnerability hypotheses.(232) (Adapted with permission from Springer Ltd). 


\section{Conclusion}

Most age-associated NDDs involve the aggregation of specific proteins within the nervous system. For several decades scientists have speculated that the key to understanding age-related NDDs may be found in the unusual biology of the prion diseases. Recently, owing largely to the advent of new disease models, this hypothesis has gained experimental momentum. In a remarkable variety of diseases, specific proteins have been found to misfold and aggregate into seeds that structurally corrupt like proteins, causing them to aggregate and form pathogenic assemblies ranging from small oligomers to large masses of amyloid.

Mitochondria and lysosomes of postmitotic cells suffer the most remarkable age-related alterations of all cellular organelles. Many mitochondria undergo enlargement and structural disorganization, while lysosomes, which are normally responsible for mitochondrial turnover, gradually accumulate an undegradable, polymeric, autofluorescent material called lipofuscin, or age pigment. We believe that these changes occur not only due to continuous oxidative stress (causing oxidation of mitochondrial constituents and autophagocytosed material), but also because of the inherent inability of cells to completely remove oxidatively damaged structures (biological 'garbage'). New findings suggest that aging is a modifiable risk factor, and it may be feasible to delay age-related diseases as a group by modulating fundamental aging mechanisms. One such mechanism is cellular senescence, which can cause chronic inflammation through the SASP.

In the last decade, a growing number of studies have shown that TERT has neuroprotective effects in cellular and animal models after a brain injury. More recently, TERT has been associated with the decrease in reactive oxygen species and DNA protection in mitochondria of neurons. Finally, the identifications of new of compounds able to increase telome- rase activity and TERT expression, specifically in brain tissue, might provide new tools for the treatment of acute and chronic neurodegenerative events.

\section{References}

1. Ross CA, Truant R. DNA repair: A unifying mechanism in neurodegeneration. Nature. 2017; 541: 34-5.

2. United Nations Department of Economic and Social Affairs Population Division. World Population Ageing 2015: Report ST/ ESA/SER.A/390 [cited Jan 16, 2017]. Available from: http://www. un.org/en/development/desa/population/publications/pdf/ageing/ WPA2015_Report.pdf.
3. Wyss-Coray T. Ageing, neurodegeneration and brain rejuvenation. Nature. 2016; 539: 180-6.

4. Hayflick L. The cell biology of human aging. N Engl J Med. 1976; 295: 1302-8.

5. Collado M, Blasco MA, Serrano M. Cellular senescence in cancer and aging. Cell. 2007; 130: 223-33.

6. Boccardi V, Pelini L, Ercolani S, Ruggiero C, Mecocci P. From cellular senescence to Alzheimer's disease: The role of tekomere shortening. Ageing Res Rev. 2015; 22: 1-8. doi: 10.1016/j. arr.2015.04.003.

7. Ransohoff RM. How neuroinflammation contributes to neurodegeneration. Science. 2016; 353: 777-83.

8. Chinta SJ, Woods G, Rane A, Demaria M, Campisi J, Andersen JK. Cellular senescence and the aging brain. Exp Gerontol. 2015; 68: 3-7.

9. Fried LP, Xue QL, Cappola AR, Ferrucci L, Chaves P, Varadhan R, et al. Nonlinear multisystem physiological dysregulation associated with frailty in older women: implications for etiology and treatment. J Gerontol A Biol Sci Med Sci. 2009; 64: 1049-57.

10. Tchkonia T, Zhu Y, Van Deursen J, Campisi J, Kirkland JL. Cellular senescence and the senescent secretory phenotype: therapeutic opportunities. J Clin Invest. 2013; 123: 966-72.

11. Kovacs GG, Adle-Biassette H, Milenkovic I, Cipriani S, van Scheppongen J, Aronica E. Linking pathways in the developing and aging brain with neurodegeneration. Neurosci. 2014; 269: 152-72.

12. Elobeid A, Libard S, Leino M, Popova SN, Alafuzoff I. Altered proteins in the aging brain. J Neuropathol Exp Neurol. 2016; 75: 316-325.

13. Brunk UT, Terman A. The mitochondrial-lysosomal axis theory of aging: accumulation of damaged mitochondria as a result of imperfect autophagocytosis. Eur J Biochem. 2002; 269: 19962002.

14. Safaiyan S, Kannaiyan N, Snaidero N, Brioschi S, Biber K, Yona S, et al. Age-related myelin degradation burdens the clearance function of microglia during aging. Nature Neurosci. 2016; 19: 995-8.

15. Nixon RA, Cataldo AM, Mathews PM. The endosomal-lysosomal system of neurons in Alzheimer's disease pathogenesis: a review. Neurochem Res. 2000; 25: 1161-72.

16. Nixon RA, Wegiel J, Kumar A, Yu WH, Peterhoff C, Cataldo A, et al. Extensive involvement of autophagy in Alzhsseimer disease: an immuno-electron microscopy study. J Neuropathol Exp Neurol. 2005; 64:113-22

17. Menzies FM, Fleming A, Rubinsztein DC. Compromised autophagy and neurodegenerative diseases. Nat Rev Neurosci. 2015; 16: $345-$ 57.

18. Taylor JP, Hardy J, Fischbeck KH. Toxic proteins in neurodegenerative disease. Science. 2002; 296: 1991-5.

19. Agorogiannis EI, Agorogiannis GI, Papadimitriou A, Hadjigeorgiou GM. Protein misfolding in neurodegenerative diseases. Neuropathol Appl Neurobiol. 2004; 30: 215-24.

20. Thal DR, Rub U, Orantes M, Braak H. Phases of A beta-deposition in the human brain and its relevance for the development of $\mathrm{AD}$ Neurology. 2002; 58: 1791- 800 .

21. Braak H, Del Tredici K, Rub U, de Vos RA, Jansen Steur EN, Braak E. Staging of brain pathology related to sporadic Parkinson's disease. Neurobiol Aging. 2003; 24: 197-211.

22. McKeith IG, Dickson DW, Lowe J, Emre M, O'Brien JT, Feldman H, et al. Diagnosis and management of dementia with Lewy bodies: third report of the DLB Consortium. Neurology. 2005; 65: 1863-72.

23. Braak H, Alafuzoff I, Arzberger T, Kretzschmar H, Del Tredici K. Staging of Alzheimer disease- associated neurofibrillary pathology using paraffin sections and immunocytochemistry. Acta Neuropathol. 2006; 112: 389-404. 
24. Neumann M, Sampathu DM, Kwong LK, Truax AC, Micsenyi MC, Chou TT, et al. Ubiquitinated TDP-43 in frontotemporal lobar degeneration and amyotrophic lateral sclerosis. Science . 2006; 314: $130-3$.

25. Braak H, Thal DR, Ghebremedhin E, Del Tredici K. Stages of the pathologic process in Alzheimer disease: Age categories from 1 to 100 years. J Neuropathol Exp Neurol. 2011; 70: 960-9.

26. Braak H, Del Tredici K. The pathological process underlying Alzheimer's disease in individuals under thirty. Acta Neuropathol. 2011; 121: 171-81.

27. Josephs KA, Murray ME, Whitwell JL, Parisi JE, Petrucelli L, Jack CR, et al. Staging TDP-43 pathology in Alzheimer's disease. Acta Neuropathol. 2014; 127: 441-50.

28. Alafuzoff I, Pikkarainen M, Al-Sarraj S, Arzberger T, Bell J, Bodi $\mathrm{I}$, et al. Interlaboratory comparison of assessments of Alzheimer disease-related lesions: A study of the Brain-Net Europe Consortium. J Neuropathol Exp Neurol 2006; 65: 740-57.

29. AlafuzoffI, Ince PG, Arzberger T, Al-Sarraj S, Bell J, Bodi I, et al. Staging/typing of Lewy body related alpha-synuclein pathology: a study of the BrainNet Europe Consortium. Acta Neuropathol. 2009; 117: $635-52$.

30. Alafuzoff I, Thal DR, Arzberger T, Bogdanovic N, Al-Sarraj S, Bodi I, et al. Assessment of b-amyloid deposits in human brain: A study of the BrainNet Europe Consortium. Acta Neuropathol. 2009; 117: 309-20.

31. Alafuzoff I, Pikkarainen M, Neumann M, Arzberger T, Al-Sarraj S, Bodi I, et al. Neuropathological assessments of the pathology in frontotemporal lobar degeneration with TDP43-positive inclusions: An inter-laboratory study by the BrainNet Europe consortium. J Neural Transm. 2015; 122: 957-72.

32. Mackenzie IR, Neumann M, Baborie A, Sampathu DM, Du Plessis D, Jaros E, et al. A harmonized classification system for FTLD-TDP pathology. Acta Neuropathol. 2011; 122: 111-3.

33. Brettschneider J, Del Tredici K, Toledo JB, Robinson JL, Irwin DJ, Grossman M, et al. Stages of pTDP-43 pathology in amyotrophic lateral sclerosis. Ann Neurol. 2013; 74: 20-38.

34. Crary JF, Trojanowski JQ, Schneider JA, Abisambra JF, Abner EL, Alafuzoff I, et al. Primary age-related tauopathy (PART): a common pathology associated with human aging. Acta Neuropathol. 2014; 128: 755-66.

35. Duyckaerts C, Braak H, Brion JP, Buée L, Del Tredici K, Goedert M, et al. PART is part of Alzheimer disease. Acta Neuropathol. 2015; 129: 749-56.

36. Jellinger KA. Lewy body-related alpha-synucleinopathy in the aged human brain. J Neural Transm. 2004; 111: 1219-35.

37. MikolaenkoI, Pletnikova O, Kawas CH, O'Brien R, Resnick SM, Crain B, et al. Alpha-Synuclein lesions in normal aging, Parkinson disease, and Alzheimer disease: Evidence from the Baltimore Longitudinal Study of Aging (BLSA). J Neuropathol Exp Neurol. 2005; 64: 156-62.

38. Boyle PA, Yu L, Wilson RS, Schneider JA, Bennett DA. Relation of neuropathology with cognitive decline among older persons without dementia. Front Aging Neu- rosci. 2013; 5: 50. doi: 10.3389/ fnagi.2013.00050.

39. Kovacs GG, Milenkovic I, Wöhrer A, Höftberger R, Gelpi E, Haberler C, et al. Non-Alzheimer neurodegenerative pathologies and their combinations are more frequent than commonly believed in the elderly brain: A community-based autopsy series. Acta Neuropathol. 2013; 126: 365-84.

40. Nakashima-Yasuda H, Uryu K, Robinson J, Xie SX, Hurtig H, Duda JE, et al. Co-morbidity of TDP-43 proteinopathy in Lewy body related diseases. Acta Neuropathol. 2007; 114: 221-9.

41. Uchino A, Takao M, Hatsuta H, Sumikura H, Nakano Y, Nogami A, et al. Incidence and extent of TDP-43 accumulation in aging human brain. Acta Neuropathol Commun. 2015; 3: 35. doi: 10.1186/ s40478-015-0215-1.

42. Rauramaa T, Pikkarainen M, Englund E, Ince PG, Jellinger K, Paetau $\mathrm{A}$, et al. Consensus recommendations on pathologic changes in the hippocampus: A postmortem multi-center inter-rater study. J Neuropathol Exp Neurol . 2013; 72: 452-61.

43. Kovacs GG, Budka H. Current concepts of neuropathological diagnostics in practice: neurodegenerative diseases. Clin Neuropathol. 2010; 29: 271-88.

44. Neumann M, Bentmann E, Dormann D, Jawaid A, DeJesusHernandez M, Ansorge O, et al. FET proteins TAF15 and EWS are selective markers that distinguish FTLD with FUS pathology from amyotrophic lateral sclerosis with FUS mutations. Brain. 2011; 134: 2595-609.

45. Kovacs GG, Majtenyi K, Spina S, Murrell JR, Gelpi E, Hoftberger $\mathrm{R}$, et al. White matter tauopathy with globular glial inclusions: a distinct sporadic frontotemporal lobar degeneration. J Neuropath Exp Neurol. 2008; 67: 963-75.

46. Wenning GK, Stefanova N, Jellinger KA, Poewe W, Schlossmacher MG. Multiple system atrophy: a primary oligodendrogliopathy. Ann Neurol. 2008; 64: 239-46.

47. Gandhi S, Abramov AY. Mechanism of oxidative stress in neurodegeneration. Oxid Med Cell Longev. 2012: 428010. doi: 10.1155/2012/428010.

48. Hoeijmakers, JH. DNA damage, aging, and cancer. N Engl J Med. $361 ; 1475-85$.

49. Madabhushi R, Pan L, Tsai LH. DNA Damage and Its Links to Neurodegeneration. Neuron. 2014; 83: 266-82.

50. Vijg J, Suh Y. Genome instability and aging. Annu Rev Physiol. 2013; 75: 645-68.

51. Krishnan V, Chow MZ, Wang Z, Zhang L, Liu B, Liu X, et al. Histone H4 lysine 16 hypoacetylation is associated with defective DNA repair and premature senescence in Zmpste24-deficient mice. Proc Natl Acad Sci USA. 2011; 108: 12325-30.

52. Peleg S, Sananbenesi F, Zovoilis A, Burkhardt S, Bahari-Javan S, Agis-Balboa RC, et al. Altered histone acetylation is associated with age-dependent memory impairment in mice. Science. 2010; 328: 753-6.

53. Adamec E, Vonsattel JP, Nixon RA. DNA strand breaks in Alzheimer's disease. Brain Res. 1999; 849: 67-77.

54. Jacobsen E, Beach T, Shen Y, Li R, Chang Y. Deficiency of the Mre11 DNA repair complex in Alzheimer's disease brains. Brain Res Mol Brain Res. 2004; 128: 1-7.

55. Mullaart E, Boerrigter ME, Ravid R, Swaab DF, Vijg J. Increased levels of DNA breaks in cerebral cortex of Alzheimer's disease patients. Neurobiol Aging. 1990; 11: 169-73.

56. Shackelford DA. DNA end joining activity is reduced in Alzheimer's disease. Neurobiol Aging. 2006; 27: 596-605.

57. Bender A, Krishnan KJ, Morris CM, Taylor GA, Reeve AK, Perry RH, $\mathrm{J}$, et al. High levels of mitochondrial DNA deletions in substantia nigra neurons in aging and Parkinson disease. Nat Genet. 2006; 38 : 515-7.

58. Kraytsberg Y, Kudryavtseva E, McKee AC, Geula C, Kowall NW, Khrapko K. Mitochondrial DNA deletions are abundant and cause functional impairment in aged human substantia nigra neurons. Nat Genet. 2006; 38: 518-20.

59. Martin LJ. Neuronal cell death in nervous system development, disease, and injury. Int J Mol Med. 2001; 7: 455-78.

60. Fujita K, Nakamura Y, Oka T, Ito H, Tamura T, Tagawa K, et al. A functional deficiency of TERA/VCP/p97 contributes to impaired DNA repair in multiple polyglutamine diseases. Nature Commun. 2013; 4: 1816. doi:10.1038/ncomms2828. 
61. McShea A, Wahl AF, Smith MA. Re-entry into the cell cycle: a mechanism for neurodegeneration in Alzheimer disease. Med Hypotheses. 1999; 52: 525-7.

62. Bonda DJ, Bajic VP, Spremo-Potpaveric B, Casadesus G, Zhu X, Smith MA, et al. Review: cell cycle aberrations and neurodegeneration. Neuropathol Appl Neurobiol. 2010; 36: 157-63.

63. McShea A, Lee HG, Petersen RB, Casadesus G, Vincent I, Linford $\mathrm{NJ}$, et al. Neuronal cell cycle re-entry mediates Alzheimer diseasetype changes. Biochim Biophys Acta. 2007; 1772: 467-72.

64. Zhu X, Lee HG, Perry G ,Smith MA. Alzheimerdisease, the two-hit hypothesis: an update. Biochim Biophys Acta. 2007; 1772: 494502.

65. Zhu X, Raina AK, Smith MA. Cell cycle events in neurons. Proliferation or death? Am J Pathol. 1999; 155: 327-9.

66. Lee HG, Casadesus G, Zhu X, Castellani RJ, McShea A, Perry G, et $a l$. Cell cycle re-entry mediated neurodegeneration and its treatment role in the pathogenesis of Alzheimer's disease. Neurochem Int. 2009; 54: 84-8.

67. Muller, M. Cellular senescence: molecular mechanisms in vivo significance, and redox considerations. Antioxid Redox Signal. 2009; 11: 59-98.

68. Fridlyanskaya I, Alekseenko L, Nikolsky N. Senescence as a general cellular response to stress: a mini-review. Exp Gerontol. 2015; 72: 124-8.

69. Liu JP. Molecular mechanisms of ageing and related diseases. Clin Exp Pharmacol Physiol. 2014; 41: 445-58.

70. Tan FC, Hutchison ER, Eitan E, Mattson MP. Are there roles for brain cell senescence in aging and neurodegenerative disorders? Biogerontology. 2014; 15: 643-60.

71. Correia-Melo C, Passos JF. Mitochondria: are they causal players in cellular senescence? Biochim Biophys Acta. 2015; 1847: 1373-9.

72. Melo A, Monteiro L, Lima RM, Oliveira DM, Cerqueira MD, El-Bacha RS. Oxidative stress in neurodegenerative diseases: mechanisms and therapeutic perspectives. Oxid Med Cell Longev. 2011; 2011: 467180. doi: 10.1155/2011/467180.

73. Tacutu R, Budovsky A, Yanai H, Fraifeld VE. Molecular links between cellular senescence, longevity and agerelated diseases - a systems biology perspective. Aging. 2011; 3: 1178-91.

74. Bhat R, Crowe EP, Bitto A, Moh M, Katsetos CD, Garcia FU, et al. Astrocyte senescence as a component of Alzheimer's disease. PLoS One. 2012; 7: e45069. doi: 10.1371/journal.pone.0045069.

75. Jurk D, Wang C, Miwa S, Maddick M, Korolchuk V, Tsolou A, et al. Postmitotic neurons develop a p21-dependent senescence-like phenotype driven by a DNA damage response. Aging Cell. 2012; 11: 996-1004.

76. Polho GB, De-Paula VJ, Cardillo G, dos Santos B, Kerr DS. Leukocyte telomere length in patients with schizophrenia: a metaanalysis. Schizophr Res. 2015; 165: 195-200.

77. Lin PY, Huang YC, Hung CF. Shortened telomere length in patients with depression: a meta-analytic study. J Psychiatric Res. 2016; 76: 84-93.

78. Tedone E, Arosio B, Colombo F, Ferri E, Asselineau D, Piette F, et al. Leukocyte telomere length in Alzheimer's disease patients with a different rate of progression. J Alzheimers Dis. 2015; 46: 761-9.

79. Forero DA, González-Giraldo Y, López-Quintero C, Castro-Vega LJ, Barreto GE, Perry G. Meta-analysis of telomere length in Alzheimerís disease. J Gerontol Ser A Biol Sci Med Sci. 2016; 71 1069-73.

80. Coppé JP, Patil CK, Rodier F, Krtolica A, Beauséjour CM, Parrinello $\mathrm{S}$, et al. A human-like senescence-associated secretory phenotype is conserved in mouse cells dependent on physiological oxygen. PLoS One. 2010; 5: e9188. doi: 10.1371/journal.pone.0009188.
81. Coppé JP, Patil CK, Rodier F, Sun Y, Muñoz DP, Goldstein J, et al. Senescence-associated secretory phenotypes reveal cellnonautonomous functions of oncogenic RAS and the p53 tumor suppressor. PLoS Biol. 2008; 6: 2853-68.

82. Davalos AR, Coppe JP, Campisi J, Desprez PY. Senescent cells as a source of inflammatory factors for tumor progression. Cancer Metastasis Rev. 2010; 29: 27383.

83. Freund A, Orjalo AV, Desprez PY, Campisi J. Inflammatory networks during cellular senescence: causes and consequences. Trends Mol Med. 2010; 16: 238-46.

84. Molofsky AV, Slutsky SG, Joseph NM, He S, Pardal R, Krishnamurthy $\mathrm{J}$, et al. Increased p16INK4a expression decreases forebrain progenitors and neurogenesis during ageing. Nature. 2006; 443: 448-52.

85. Hinkal GW, Gatza CE, Parikh N, Donehower LA. Altered senescence, apoptosis, and DNA damage response in a mutant p53 model of accelerated aging. Mech Ageing Dev. 2009; 130: 262-71.

86. Møller P, Løhr M, Folkmann JK, Mikkelsen L, Loft S. Aging and oxidatively damaged nuclear DNA in animal organs. Free Radic Biol Med. 2010; 48: 1275-85.

87. Poon HF, Calabrese V, Scapagnini G, Butterfield DA. Free radicals and brain aging. Clin Geriatr Med. 2004; 20: 329-59.

88. Douglas PM, Dillin A. Protein homeostasis and aging in neurodegeneration. J Cell Biol. 2010; 190: 719-29.

89. Foster TC. Calcium homeostasis and modulation of synaptic plasticity in the aged brain. Aging Cell. 2007; 6: 319-25.

90. Boveris A, Navarro A. Brain mitochondrial dysfunction in aging. IUBMB Life. 2008; 60: 308-14.

91. Sulzer D, Mosharov E, Talloczy Z, Zucca FA, Simon JD, Zecca L. Neuronal pigmented autophagic vacuoles: lipofuscin, neuromelanin, and ceroid as macroautophagic responses during aging and disease. J Neurochem. 2008; 106: 24-36.

92. Blalock EM, Chen KC, Sharrow K, Herman JP, Porter NM, Foster TC, et al. Gene microarrays in hippocampal aging: statistical profiling identifies novel processes correlated with cognitive impairment. J Neurosci. 2003; 23: 3807-19.

93. Park SK, Prolla TA. Lessons learned from gene expression profile studies of aging and caloric restriction. Ageing Res Rev. 2005; 4: $55-65$.

94. Salminen A, Ojala J, Kaarniranta K, Haapasalo A, Hiltunen M, Soininen H. Astrocytes in the aging brain express characteristics of senescence-associated secretory phenotype. Eur J Neurosci. 2011; 34: 3-11.

95. Ota Y, Zanetti AT, Hallock RM. The role of astrocytes in the regulation of synaptic plasticity and memory formation. Neural Plast. 2013; 185463. doi: 10.1155/2013/185463.

96. Streit WJ. Microglia and the response to brain injury. Ernst Schering Res Found Workshop. 2002; 39: 11-24.

97. Streit WJ. Microglia as neuroprotective, immunocompetent cells of the CNS. Glia . 2002; 40: 133-9.

98. Benarroch EE. Neuron-astrocyte interactions: partnership for normal function and disease in the central nervous system. Mayo Clin Proc. 2005; 80: 1326-38

99. Magistretti PJ. Neuron-glia metabolic coupling and plasticity. J Exp Biol. 2006; 209: 2304-11.

100. Mather KA, Jorm AF, Parslow RA, Christensen H. Is telomere length a biomarker of aging? A review. J Gerontol A Biol Sci Med Sci. 2011; 66: 202-13

101. de Lange T. Protection of mammalian telomeres. Oncogene. 2002; 21: 532-40.

102. von Zglinicki T. Oxidative stress shortens telomeres. Trends Biochem Sci. 2002; 27: 339-44.

103. Blackburn EH. Telomere states and cell fates. Nature. 2000; 408: 
53-6.

104. Flanary BE, Sammons NW, Nguyen C, Walker D, Streit WJ. Evidence that aging and amyloid promote microglial cell senescence. Rejuvenation Res. 2007; 10: 61-74.

105. Spilsbury A, Miwa S, Attems J, Saretzki G. The role of telomerase protein TERT in Alzheimer's disease and in tau-related pathology in vitro. J Neurosci. 2015; 35: 1659-74.

106. Kang HJ, Choi YS, Hong SB, Kim KW, Woo RS, Won SJ, et al. Ectopic expression of the catalytic subunit of telomerase protects against brain injury resulting from ischemia and NMDA-induced neurotoxicity. J Neurosci. 2004; 24: 1280-87.

107. Li J, Qu Y, Chen D, Zhang L, Zhao F, Luo L, et al. The neuroprotective role and mechanisms of TERT in neurons with oxygen-glucose deprivation. Neuroscience . 2013; 252: 346-58.

108. Gonzalez-Giraldo Y, Forero DA, Echeverria V, Gonzalez J, AvilaRodriguez M, Garcia-Segura LM, et al. Neuroprotective effects of the catalytic subunit of telomerase: a potential therapeutic target in the Central Nervous System. Age Res Rev. 2016; 28: 37-45.

109. Haendeler J, Hoffmann J, Brandes RP, Zeiher AM, Dimmeler S. Hydrogen peroxide triggers nuclear export of telomerase reverse transcriptase via Src kinase family-dependent phosphorylation of tyrosine 707. Mol Cell Biol. 2003; 23: 4598-610.

110. Jakob S, Schroeder P, Lukosz M, Büchner N, Spyridopoulos I, Altschmied J, et al. Nuclear protein tyrosine phosphatase Shp-2 is one important negative regulator of nuclear export of telomerase reverse transcriptase. J Biol Chem. 2008; 283: 33155-61.

111. Chung J, Khadka P, Chung IK. Nuclear import of hTERT requires bipartite nuclear localization signal and Akt-mediated phosphorylation. J Cell Sci. 2012. 125: 2684-97.

112. Sharma NK, Reyes A, Green P, Caron MJ, Bonini MG, Gordon $\mathrm{DM}$, et al. Human telomerase acts as a hTR-independent reverse transcriptase in mitochondria. Nucleic Acids Res. 2012; 40: 712-25.

113. Ahmed S, Passos JF, Birket MJ, Beckmann T, Brings S, Peters H, et al. Telomerase does not counteract telomere shortening but protects mitochondrial function under oxidative stress. J Cell Sci. 2008; 121: 1046-53.

114. Santos JH, Meyer JN, Skorvaga M, Annab LA, Van Houten B. Mitochondrial hTERT exacerbates free-radical-mediated mtDNA damage. Aging Cell. 2004; 3: 399-411.

115. Smith JA, Park S, Krause JS, Banik NL. Oxidative stress, DNA damage, and the telomeric complex as therapeutic targets in acute neurodegeneration. Neurochem Int. 2013; 62: 764-75.

116. Li J, Tang B, Qu Y, Mu D. Telomerase reverse transcriptase: a novel neuroprotective mechanism involved in neonatal hypoxic-ischemic brain injury. Int J Dev Neurosci. 2011; 29: 867-72.

117. Eitan E, Tichon A, Gazit A, Gitler D, Slavin S, Priel E. Novel telomerase-increasing compound in mouse brain delays the onset of amyotrophic lateral sclerosis. EMBO Mol Med. 2012; 4: 313-29.

118. Franceschi C, Bonafè $M$, Valensin S, Olivieri F, De Luca M, Ottaviani $\mathrm{E}$, et al. Inflamm-aging. An evolutionary perspective on immunosenescence. Ann NY Acad Sci. 2000; 908: 244-54

119. Franceschi C, Campisi J. Chronic Inflammation (Inflammaging) and Its Potential Contribution to Age-Associated Diseases. J Gerontol A Biol Sci Med Sci. 2014; 69: S4-9.

120. Biagi E, Candela M, Franceschi C, Brigidi P. The aging gut microbiota: new perspectives. Ageing Res Rev. 2011; 10: 428-9.

121. Campisi J, d'Adda di Fagagna F. Cellular senescence: when bad things happen to good cells. Nat Rev Mol Cell Biol. 2007; 8: 72940.

122. Baker DJ, Wijshake T, Tchkonia T, LeBrasseur NK, Childs BG, van de Sluis B, et al. Clearance of p16Ink4a-positive senescent cells delays ageing-associated disorders. Nature. 2011; 479: 232-6.
123. Zhang B, Gaiteri C, Bodea LG, Wang Z, McElwee J, Podtelezhnikov $\mathrm{AA}$, et al. Integrated systems approach identifies genetic nodes and networks in late-onset Alzheimer's disease. Cell. 2013; 153: $707-$ 20.

124. Guerreiro R, Wojtas A, Bras J, Carrasquillo M, Rogaeva E, Majounie $\mathrm{E}$, et al. TREM2 variants in Alzheimer's disease. N Engl J Med. 2013; 368: 117-27.

125. Bradshaw EM, Chibnik LB, Keenan BT, Ottoboni L, Raj T, Tang A, et al. CD33 Alzheimer's disease locus: altered monocyte function and amyloid biology. Nat Neurosci. 2013; 16: 848-50.

126. Griciuc A, Serrano-Pozo A, Parrado AR, Lesinski AN, Asselin CN, Mullin K, et al. Alzheimer's disease risk gene CD33 inhibits microglial uptake of amyloid beta. Neuron. 2013; 78: 631-43.

127. Heneka M, Carson MJ, El Khoury J, Landreth GE, Brosseron F, Feinstein DL, et al. Neuroinflammation in Alzheimer's disease. Lancet Neurol. 2015; 14: 388-405.

128. Bamberger ME, Harris ME, McDonald DR, Husemann J, Landreth GE. A cell surface receptor complex for fibrillar beta-amyloid mediates microglial activation. J Neurosci. 2003; 23: 2665-74.

129. Paresce DM, Ghosh RN, Maxfield FR. Microglial cells internalize aggregates of the Alzheimer's disease amyloid beta-protein via a scavenger receptor. Neuron. 1996; 17: 553-65.

130. Stewart CR, Stuart LM, Wilkinson K, van Gils JM, Deng J, Halle A, et al. CD36 ligands promote sterile inflammation through assembly of a Toll-like receptor 4 and 6 heterodimer. Nat Immunol. 2010; 11: 155-61.

131. Liu Y, Walter S, Stagi M, Cherny D, Letiembre M, Schulz-Schaeffer $\mathrm{W}$, et al. LPS receptor (CD14): a receptor for phagocytosis of Alzheimer's amyloid peptide. Brain. 2005; 128: 1778-89.

132. El Khoury JB, Moore KJ, Means TK, Leung J, Terada K, Toft M, et al. CD36 mediates the innate host response to beta-amyloid. J Exp Med. 2003; 197: 1657-66.

133. Sheedy FJ, Grebe A, Rayner KJ, Kalantari P, Ramkhelawon B, Carpenter SB, et al. CD36 coordinates NLRP3 inflammasome activation by facilitating intracellular nucleation of soluble ligands into particulate ligands in sterile inflammation. Nat Immunol. 2013; 14: 812-20.

134. Heppner FL, Ransohoff RM, Becher B. Imune attack: the role of inflammation in Alzheimer's disease. Nat Rev Neurosci. 2015; 16 : 358-72.

135. Rugarli EI, Langer T. Mitochondrial quality control: a matter of life and death for neurons. EMBO J. 2012; 31: 1336-49.

136. Fivenson EM, Lautrup S, Sun N, Scheibye-Knudsen M, Stevnsner $\mathrm{T}$, Nilsen $\mathrm{H}$, et al. Mitpophagy in neurodegeneration and aging. Neurochem Int. 2017; 109: 202-209

137. Rubinsztein DC, Mariño G, Kroemer G. Autophagy and aging. Cell. 2011; 146: 682-95.

138. Madeo F, Tavernarakis N, Kroemer G. Can autophagy promote longevity? Nat Cell Biol. 2010; 12: 842-6.

139. Hara T, Nakamura K, Matsui M, Yamamoto A, Nakahara Y, SuzukiMigishima R, et al. Suppression of basal autophagy in neural cells causes neurodegenerative disease in mice. Nature. 2006; 441: 885-9.

140. Park D, Jeong H, Lee MN, Koh A, Kwon O, Yang YR, et al. Resveratrol induces autophagy by directly inhibiting mTOR through ATP competition. Sci Rep. 2016; 6: 21772. doi: 10.1002/ mnfr.201700610.

141. Komatsu M, Waguri S, Chiba T, Murata S, Iwata J, Tanida I, et al. Loss of autophagy in the central nervous system causes neurodegeneration in mice. Nature. 2006; 441: 880-4.

142. Wallace DC. A mitochondrial bioenergetic etiology of disease. J Clin Invest. 2013; 123: 1405-12. 
143. Lopez-Otín C, Blasco MA, Partridge L, Serrano M, Kroemer G. The hallmarks of aging. Cell. 2013; 153: 1194-217.

144. Scheibye-Knudsen M, Fang EF, Croteau DL, Wilson DM 3rd, Bohr VA. Protecting the mitochondrial powerhouse. Trends Cell Biol. 2015; 25 : 158-70.

145. Lemasters JJ. Selective mitochondrial autophagy, or mitophagy, as a targeted defense against oxidative stress, mitochondrial dysfunction, and aging. Rejuvenation Res. 2005; 8: 3-5.

146. Palikaras K, Tavernarakis N. Mitophagy in neurodegeneration and aging. Front. Genet. 2012; 3: 297. doi: 10.3389/fgene.2012.00297.

147. Ryan BJ, Hoek S, Fon EA, Wade-Martins R. Mitochondrial dysfunction and mitophagy in Parkinson's: from familial to sporadic disease. Trends Biochem Sci. 2015; 40: 200-10.

148. Khalil B, El Fissi N, Aouane A, Cabirol-Pol MJ, Rival T, Liévens JC. PINK1-induced mitophagy promotes neuroprotection in Huntington's disease. Cell death Dis. 2015; 6: e1617. doi: 10.1038/ cddis.2014.581

149. Ye X, Sun X, Starovoytov V, Cai Q. Parkin-mediated mitophagy in mutant hAPP neurons and Alzheimer's disease patient brains. Hum Mol Genet. 2015; 24 : 2938-51.

150. Sun N, Yun J, Liu J, Malide D, Liu C, Rovira II, et al. Measuring in vivo mitophagy. Mol Cell. 2015; 60: 685-96.

151. Li Y, Huang TT, Carlson EJ, Melov S, Ursell PC, Olson JL, et al. Dilated cardiomyopathy and neonatal lethality in mutant mice lacking manganese superoxide dismutase. Nat Genet. 1995; 11: 376-81.

152. Wilkins HM, Kirchhof D, Manning E, Joseph JW, Linseman DA. Mitochondrial glutathione transport is a key determinant of neuronal susceptibility to oxidative and nitrosative stress. J Biol Chem. 2013; 288: 5091-101.

153. Hill BG, Benavides GA, Lancaster JR, Jr., Ballinger S, Dell'italia $\mathrm{L}$, Zhang $\mathrm{J}$, et al. Integration of cellular bioenergetics with mitochondrial quality control and autophagy. Biol Chem. 2012; 393: $1485-512$.

154. Takacs-Vellai K, Vellai T, Puoti A, Passannante M, Wicky C, Streit $\mathrm{A}$, et al. Inactivation of the autophagy gene bec-1 triggers apoptotic cell death in C. elegans. Curr Biol. 2005; 15: 1513-17.

155. Juhasz G, Erdi B, Sass M, Neufeld TP. Atg7- dependent autophagy promotes neuronal health, stress tolerance, and longevity but is dispensable for metamorphosis in Drosophila. Genes Dev. 2007; 21: 3061- 66.

156. Toth ML, Sigmond T, Borsos E, Barna J, Erdelyi P, Takacs-Vellai K, et al. Longevity pathways converge on autophagy genes to regulate life span in Caenorhabditis elegans. Autophagy. 2008; 4: 330-8.

157. Harrison DE, Strong R, Sharp ZD, Nelson JF, Astle CM, Flurkey $\mathrm{K}$, et al. Rapamycin fed late in life extends lifespan in genetically heterogeneous mice. Nature. 2009; 460: 392-5.

158. Vellai T, Takacs-Vellai K, Sass M, Klionsky DJ. The regulation of aging: does autophagy underlie longevity? Trends Cell Biol. 2009; 19: 487-94.

159. Vellai T. Autophagy genes and ageing. Cell Death Differ. 2009; 16: 94-102.

160. Morselli E, Maiuri MC, Markaki M, Megalou E, Pasparaki A, Palikaras $\mathrm{K}$, et al. Caloric restriction and resveratrol promote longevity through the Sirtuin-1-dependent induction of autophagy. Cell Death Dis. 2010; 1: e10. doi: 10.1038/cddis.2009.8

161. Bjedov I, and Partridge L. A longer and healthier life with TOR downregulation: genetics and drugs. Biochem Soc Trans. 2011; 39: 46065.

162. Mai S, Muster B, Bereiter-Hahn J, Jendrach M. Autophagy proteins LC3B, ATG5 and ATG12 participate in quality control after mitochondrial damage and influence lifespan. Autophagy. 2012; 8: 47-62.
163. Pyo JO, Yoo SM, Ahn HH, Nah J, Hong SH, Kam TI, et al. Overexpression of Atg5 in mice activates autophagy and extends lifespan. Nat Commun. 2013; 4: 2300. doi: 10.1038/ ncomms 3300

164. Li J, Kim SG, Blenis J. Rapamycin: one drug, many effects. Cell Metab. 2014; 19: 373-9.

165. Lamming DW, Ye L, Katajisto P, Goncalves MD, Saitoh M, Stevens $\mathrm{DM}$, et al. Rapamycin-induced insulin resistance is mediated by mTORC2 loss and uncoupled from longevity. Science. 2012; 335: 1638-43.

166. Halloran J, Hussong SA, Burbank R, Podlutskaya N, Fischer KE, Sloane LB, et al. Chronic inhibition of mammalian target of rapamycin by rapamycin modulates cognitive and non-cognitive components of behavior throughout lifespan in mice. Neuroscience. 2012; 223: 102-13.

167. Majumder S, Caccamo A, Medina DX, Benavides AD, Javors MA, Kraig E, et al. Lifelong rapamycin administration ameliorates agedependent cognitive deficits by reducing IL-1beta and enhancing NMDA signaling. Aging Cell. 2012; 11: 326-35.

168. Richardson A. Rapamycin, anti-aging, and avoiding the fate of Tithonus. J Clin Invest. 2013; 123: 3204-06.

169. Lin AL, Zheng W, Halloran JJ, Burbank RR, Hussong SA, Hart $\mathrm{MJ}$, et al. Chronic rapamycin restores brain vascular integrity and function through NO synthase activation and improves memory in symptomatic mice modeling Alzheimer's disease. J Cereb Blood Flow Metab. 2013; 33: 1412-21.

170. Richardson A, Galvan V, Lin AL, Oddo S. How longevity research can lead to therapies for Alzheimer's disease: The rapamycin story. Exp Gerontol. 2015; 68: 51-8.

171. Liu Y, Diaz V, Fernandez E, Strong R, Ye L, Baur JA, et al. Rapamycin-induced metabolic defects are reversible in both lean and obese mice. Aging. 2014; 6: 742-54.

172. Fok WC, Chen Y, Bokov A, Zhang Y, Salmon AB, Diaz V, et al. Mice fed rapamycin have an increase in lifespan associated with major changes in the liver transcriptome. PLoS One. 2014; 9: e83988. doi: 10.1371/journal.pone.0083988

173. Zhang Y, Bokov A, Gelfond J, Soto V, Ikeno Y, Hubbard G, et al. Rapamycin extends life and health in C57BL/6 mice. J Gerontol A Biol Sci Med Sci. 2014; 69: 119-30.

174. Tardif S, Ross C, Bergman P, Fernandez E, Javors M, Salmon A, et al. Testing efficacy of administration of the antiaging drug rapamycin in a nonhuman primate, the common marmoset. J Gerontol A Biol Sci Med Sci. 2015; 70: 577-88.

175. Miller RA, Harrison DE, Astle CM, Fernandez E, Flurkey K, Han M, et al. Rapamycin-mediated lifespan increase in mice is dose and sex dependent and metabolically distinct from dietary restriction. Aging Cell. 2014; 13: 468-77.

176. Hansen M, Taubert S, Crawford D, Libina N, Lee SJ, Kenyon C. Lifespan extension by conditions that inhibit translation in Caenorhabditis elegans. Aging Cell. 2007; 6: 95-110.

177. Selman C, Tullet JM, Wieser D, Irvine E, Lingard SJ, Choudhury AI, et al. Ribosomal protein $\mathrm{S} 6$ kinase 1 signaling regulates mammalian life span. Science. 2009; 326: 140-4.

178. Redmann M, Darley-Usmar V, Zhang J. The Role of Autophagy, Mitophagy and Lysosomal Functions in Modulating Bioenergetics and Survival in the Context of Redox and Proteotoxic Damage: Implications for Neurodegenerative Diseases. Aging Dis. 2016; 7: 150-62.

179. Jolly RD, Brown S, Das AM, Walkley SU. Mitochondrial dysfunction in the neuronal ceroid-lipofuscinoses (Batten disease). Neurochem Int. 2002; 40: 565-71.

180. Rouschop KM, Ramaekers CH, Schaaf MB, Keulers TG, Savelkouls $\mathrm{KG}$, Lambin $\mathrm{P}$, et al. Autophagy is required during cycling hypoxia 
to lower production of reactive oxygen species. Radiother Oncol. 2009; 92: 411- 6.

181. Park BC, Park SH, Paek SH, Park SY, Kwak MK, Choi HG, et al. Chloroquine-induced nitric oxide increase and cell death is dependent on cellular GSH depletion in A172 human glioblastoma cells. Toxicol Lett. 2008; 178: 52-60.

182. Farombi EO. Genotoxicity of chloroquine in rat liver cells: protective role of free radical scavengers. Cell Biol Toxicol. 2006; 22: 159-67.

183. Park J, Choi K, Jeong E, Kwon D, Benveniste EN, Choi C. Reactive oxygen species mediate chloroquine-induced expression of chemokines by human astroglial cells. Glia. 2004; 47: 9-20.

184. Yamasaki R, Zhang J, Koshiishi I, Sastradipura Suniarti DF, Wu Z, Peters $\mathrm{C}$, et al. Involvement of lysosomal storage-induced p38 MAP kinase activation in the overproduction of nitric oxide by microglia in cathepsin D-deficient mice. Mol Cell Neurosci. 2007; 35: 57384.

185. Yang DS, Stavrides P, Mohan PS, Kaushik S, Kumar A, Ohno M, et al. Reversal of autophagy dysfunction in the TgCRND8 mouse model of Alzheimer's disease ameliorates amyloid pathologies and memory deficits. Brain. 2011; 134: 258-77.

186. Tizon B, Sahoo S, Yu H, Gauthier S, Kumar AR, Mohan P, et al. Induction of autophagy by cystatin $\mathrm{C}$ : a mechanism that protects murine primary cortical neurons and neuronal cell lines. PLoS ONE. 2010; 5: e9819. doi: 10.1371\%2Fjournal.pone.0009819.

187. Mueller-Steiner S, Zhou Y, Arai H, Roberson ED, Sun B, Chen J, et al. Antiamyloidogenic and neuroprotective functions of cathepsin B: implications for Alzheimer's disease. Neuron. 2006; 51: 703-14.

188. Levonen AL, Hill BG, Kansanen E, Zhang J, Darley-Usmar VM. Redox regulation of antioxidants, autophagy, and the response to stress: Implications for electrophile therapeutics. Free Radic Biol Med. 2014; 71: 196-207.

189. Mitchell T, Chacko B, Ballinger SW, Bailey SM, Zhang J, Darley-Usmar V. Convergent mechanisms for dysregulation of mitochondrial quality control in metabolic disease: implications for mitochondrial therapeutics. Biochem Soc Trans. 2013; 41: 127-33.

190. Jegga AG, Schneider L, Ouyang X, Zhang J. Systems biology of the autophagy-lysosomal pathway. Autophagy. 2011; 7: 477-89.

191. Jaber N, Dou Z, Chen JS, Catanzaro J, Jiang YP, Ballou LM, et al. Class III PI3K Vps34 plays an essential role in autophagy and in heart and liver function. Proc Natl Acad Sci USA. 2012; 109: 2003-8.

192. Jaber N, Dou Z, Lin RZ, Zhang J, Zong WX. Mammalian PIK3C3/ VPS34: the key to autophagic processing in liver and heart. Autophagy. 2012; 8: 707-8.

193. Wani WY, Boyer-Guittaut M, Dodson M, Chatham J, Darley-Usmar V, Zhang J. Regulation of autophagy by protein post-translational modification. Lab Invest,. 2015; 95: 14-25.

194. Miwa S, Czapiewski R, Wan T, Bell A, Hill KN, von Zglinicki T, et al. Decreased mTOR signalling reduces mitochondrial ROS in brain via accumulation of the telomerase protein TERT within mitochondria. Aging. 2016; 8: 2551-67.

195. Miwa S, Saretzki G. Telomerase and mTOR in the brain: the mitochondria connection. Neural Regen Res. 2017; 12: 358-61.

196. Landreh M, Sawaya MR, Hipp MS, Eisenberg DS, Wutrich K, Harti FU. The formation, function and regulation of amyloids: insights from structural biology. J Intern Med. 2016; 280: 164-76.

197. Uversky VN, Dunker AK. The case for intrinsically disordered proteins playing contributory roles in molecular recognition without a stable 3D structure. F1000 Biol Rep. 2013; 5: 1. doi: $10.3410 \% 2$ FB5-1.

198. Malinovska L, Kroschwald S, Alberti S. Protein disorder, prion propensities, and self-organizing macromolecular collectives. Biochim Biophys Acta. 2013; 1834: 918-31.
199. Balch WE, Morimoto RI, Dillin A, Kelly JW. Adapting proteostasis for disease intervention. Science. 2008; 319: 916-9.

200. Hartl FU, Bracher A, Hayer-Hartl M. Molecular chaperones in protein folding and proteostasis. Nature. 2011; 475: 324-32.

201. Braak, H, Braak, E. Neuropathological stageing of Alzheimer-related changes. Acta Neuropathol. 1991; 82: 239-59.

202. Jucker M, Walker LC. Self-propagation of pathogenic protein aggregates in neurodegenerative diseases. Nature. 2013; 501: 4551.

203. Dobson CM. Protein folding and misfolding. Nature. 2003; 426: 884-90.

204. Selkoe DJ. Folding proteins in fatal ways. Nature. 2003; 426: 900-4.

205. Kelly JW. Alternative conformations of amyloidogenic proteins govern their behavior. Curr Opin Struct Biol. 1996; 6: 11-7.

206. Ankarcrona M, Winblad B, Monteiro C, Fearns C, Powers ET, Johansson J, et al. Current and future treatment of amyloid diseases. J Intern Med. 2016; 280: 177-202.

207. Andrade C. A peculiar form of peripheral neuropathy; familiar atypical generalized amyloidosis with special involvement of the peripheral nerves. Brain. 1952; 75: 408-27.

208. Glenner GG, Terry W, Harada M, Isersky C, Page D. Amyloid fibril proteins-proof of homology with immunoglobulin light chains by sequence analyses. Science. 1971; 172: 1150-1.

209. Linke RP. Characteristics of a serum substance (SAA) antigenically related to amyloif fibril protein AA. Zeitschrift Fur ImmunitatsForschung Experimentelle Und Klinische Immunologie. 1975; 150: 219.

210. Glenner GG, Wong CW. Alzheimer's disease and Down's syndrome: sharing of a unique cerebrovascular amyloid fibril protein. Biochem Biophys Res Commun. 1984; 122: 1131-5.

211. Sipe JD, Benson MD, Buxbaum JN, Ikeda S, Merlini G, Saraiva MJ, et al. Nomenclature 2014: Amyloid fibril proteins and clinical classification of the amyloidosis. Amyloid. 2014; 21: 221-4.

212. Eisenberg D, Jucker M. The amyloid state of proteins in human diseases. Cell. 2012; 148: 1188-203.

213. Bonar L, Cohen AS, Skinner MM. Characterization of amyloid fibril as a cross-beta protein. Proc Soc Exp Biol Med. 1969; 131: 1373. doi: 10.3181/00379727-131-34110.

214. Westermark GT, Fandrich M, Westermark P. AA amyloidosis: pathogenesis and targeted therapy. Ann Rev Pathol. 2015; 10: 32144.

215. Wadsworth JD, Collinge J. Molecular pathology of human prion disease. Acta Neuropathol. 2011; 121: 69-77.

216. Scott MR, Will R, Ironside J, Nguyen HO, Tremblay P, DeArmond $\mathrm{SJ}$, et al. Compelling transgenetic evidence for transmission of bovine spongiform encephalopathy prions to humans. Proc Natl Acad Sci USA. 1999; 96: 15137-42.

217. Eisele YS, Monteiro C, Fearns C, Encalada SE, Wiseman RL, Powers ET, et al. Targeting protein aggregation for the treatment of degenerative diseses. Nat Rev Drug Discov. 2015; 14: 75980.

218. Soto C. Unfolding the role of protein misfolding in neurodegenerative diseases. Nat Rev Neurosci. 2003; 4: 49-60.

219. Prusiner SB. Novel proteinaceous infectious particles cause scrapie. Science. 1982; 216: 136-44.

220. Prusiner SB. Cell biology. A unifying role for prions in neurodegenerative diseases. Science. 2012; 336: 1511-13.

221. Frost B, Diamond MI. Prion-like mechanisms in neurodegenerative diseases. Nat Rev Neurosci. 2010; 11: 155-9.

222. Brettschneider J, Del Tredici K, Lee VM, Trojanowski JQ. Spreading of pathology in neurodegenerative diseases: a focus on human studies. Nat Rev Neurosci. 2015; 16: 109-20. 
223. Prusiner SB. Prions. Proc Natl Acad Sci USA. 1998; 95, $13363-$ 83.

224. Collinge J. Prion diseases of humans and animals: their causes and molecular basis. Annu Rev Neurosci. 2001; 24: 519-50.

225. Aguzzi A, Calella AM. Prions: protein aggregation and infectious diseases. Physiol. Rev. 2009; 89: 1105-52.

226. Caughey B, Baron GS, Chesebro B, Jeffrey M. Getting a grip on prions: oligomers, amyloids, and pathological membrane interactions. Annu Rev Biochem. 2009; 78: 177-204.

227. Jarrett JT, Lansbury PT Jr. Seeding “one-dimensional crystallization” of amyloid: a pathogenic mechanism in Alzheimer's disease and scrapie? Cell. 1993; 73: 1055-8.

228. Brundin P, Melki R, Kopito R. Prion-like transmission of protein aggregates in neurodegenerative diseases. Nat Rev Mol Cell Biol. 2010; 11: 301-7.
229. Guest WC, Silverman JM, Pokrishevsky E, O'Neill MA, Grad LI, Cashman NR. Generalization of the prion hypothesis to other neurodegenerative diseases: an imperfect fit. J Toxicol Environ Health A. 2011; 74: 1433-59.

230. Aguzzi A. Cell biology: Beyond the prion principle. Nature. 2009; 459: 924-5.

231. Ashe KH, Aguzzi A. Prions, prionoids and pathogenic proteins in Alzheimer disease. Prion. 2013; 7: 55-9.

232. Walsh DM, Selkoe DJ. A critical appraisal of the pathogenic protein spread hypothesis of neurodegeneration. Nat Rev Neurosci. 2016; 17: 251-60.

233. Mattson MP, Magnus T. Ageing and neuronal vulnerability. Nat Rev Neurosci. 2006; 7: 278-94.

234. Jackson WS. Selective vulnerability to neurodegenerative disease: the curious case of Prion Protein. Dis Model Mech. 2014; 7: 21-9. 